\title{
A Qualitative and Quantitative Analysis of Remanufacturing Research
}

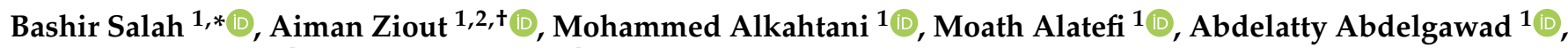 \\ Ahmed Badwelan ${ }^{1}(1)$ and Umar Syarif ${ }^{1}$ (1)
}

1 Industrial Engineering Department, College of Engineering, King Saud University, Riyadh 11421, Saudi Arabia; ziout@uaeu.ac.ae (A.Z.); moalkahtani@ksu.edu.sa (M.A.); malatefi@ksu.edu.sa (M.A.); aesayed@ksu.edu.sa (A.A.); abadwelan@ksu.edu.sa (A.B.); usuryahatmaja@ksu.edu.sa (U.S.)

2 Mechanical Engineering Department, College of Engineering, United Arab Emirates University, Al Ain 15551, United Arab Emirates

* Correspondence: bsalah@ksu.edu.sa

† August 2014-June 2015: Affiliation 1; July 2015-untill now: Affiliation 2.

Citation: Salah, B.; Ziout, A.; Alkahtani, M.; Alatefi, M.; Abdelgawad, A.; Badwelan, A.; Syarif, U. A Qualitative and Quantitative Analysis of Remanufacturing Research. Processes 2021, 9, 1766. https://doi.org/ $10.3390 /$ pr9101766

Academic Editor: Shixin Liu

Received: 8 September 2021

Accepted: 28 September 2021

Published: 1 October 2021

Publisher's Note: MDPI stays neutral with regard to jurisdictional claims in published maps and institutional affiliations.

Copyright: (c) 2021 by the authors. Licensee MDPI, Basel, Switzerland. This article is an open access article distributed under the terms and conditions of the Creative Commons Attribution (CC BY) license (https:/ / creativecommons.org/licenses/by/ $4.0 /)$.

\begin{abstract}
The advancements in human lifestyle result in growth in daily demands of products, and accordingly, an increased rate of manufacturing. However, the resources on the planet Earth are limited, thus depleting day-by-day. More goods also contribute to more end-of-life (EOL) dumping or even before EOL in some cases. Therefore, an interest in remanufacturing has appeared, and it offers a solution that can solve or perhaps mitigate the risks of consuming more resources and increasing waste. Remanufacturing is a procedure of bringing used products to "like-new" functional status with a matching warranty. However, due to its relative novelty in terms of research field and industry, remanufacturing is poorly understood. People often mix it with other terms such as recycling, reconditioning, or repair. Therefore, in this research, the focus is on the remanufacturing systems' definition, relevance, main phases, case studies, and solution methods proposed by various researchers. The word 'remanufacturing' is clearly described in this paper by differentiating it from alternative green manufacturing initiatives. Both qualitative and quantitative analysis of literature are performed. The quantitative analysis is conducted using a bibliometric method. For quantitative analysis, a systematic approach is utilized for research papers' selection. The qualitative analysis has been carried out by discussing different aspects of remanufacturing and how the researchers are working on its different domains and phases. The review showed that researchers focused on some phases more as compared with others. Moreover, it is also revealed from the literature that the common solutions methods applied in this domain are optimization techniques. Future research directions are also identified and presented.
\end{abstract}

Keywords: sustainable manufacturing; remanufacturing; reconditioning; recycling

\section{Introduction}

In every field, researchers and industries are looking for sustainable development and thus reducing waste. Therefore, the manufacturing domain is not left behind, and a great deal of emphasis has been placed on sustainable development. By encouraging secondary market processes (reuse, recycling, recovery, and so on), sustainable development is addressed. The significance of these processes is that, by prolonging the life of goods and components, they help restrict landfills, so they take longer before disposal is required [1]. Hence, sustainable development remanufacturing can be considered as more environmentally friendly than usual manufacturing because it can be profitable in terms of economy as well as reducing burden on environment.

Remanufacturing is one such process. Researchers now agree that remanufacturing is a critical strategy for achieving long-term manufacturing sustainability [2-7]. Remanufac- 
turing, an industrial process of recovery methods, is carried out to restore a used product to its original form. This activity usually applies particularly to complex electromechanical, electronic, and mechanical products that have cores, when recovered, and will have a high added value compared to their market value and original cost [8]. Remanufacturing activities can be found in many different manufacturing and industrial sectors $[9,10]$. It is a process used by manufacturers to save and improve the reuse of resources, protect the environment, and reduce waste [11]. Remanufacturing also saves costs in energy and materials [12]. The remanufacturing process is becoming more popular due to the increase in recent awareness by corporate leaders and governmental regulations [13]. Many different manufacturing companies have created and developed new policies, strategies, and procedures related to remanufacturing and product EOL (end of life) to benefit from used products [14]. The potential benefits of remanufacturing have sparked widespread interest. The economic benefits are largely derived from cost savings (up to 50 percent) arising from energy saving (up to 60 percent) and material cost reductions (up to 70 percent) [15]. In 2008, researchers from the Center for Sustainable Systems at the University of Michigan conducted a life cycle assessment study for automotive engines [16]. The results revealed that, through the remanufacturing process for engines, $68-83 \%$ less energy is required and $73-87 \%$ fewer carbon dioxide emissions. Apart from that, other emissions were also significantly reduced. The production of solid waste was reduced by $65-80 \%$, and the consumption of raw materials was reduced by $26-90 \%$. Remanufactured products are expected to save the equivalent of 400 trillion Btu of energy per year [17]. It is reported that when a product is remanufactured rather than newly made, the greenhouse gas emissions associated with its life can be decreased by 79-99 percent [18]. Moreover, the raw material consumption is reduced by $80-98 \%$ in remanufacturing of industrial equipment when compared against producing it from scratch [18]. Hence, remanufacturing has several advantages such as conservation of materials, reduced energy consumption during manufacturing, less waste, decreased disposal costs, and lower price for equivalent quality, to name a few.

Remanufacturing is divided into phases, such as design and development, collection, inspection, disassembly, inspection of components, and cleaning/re-assembly [19]. In each of these phases, different activities are carried out to make up the complete remanufacturing process and produce products with the same quality as new ones. More details of these phases are presented in the subsequent sections. Apart from the above-mentioned phases, there are also different activities in the remanufacturing process that will be discussed in this paper.

This paper will review some of the major phases and steps involved in remanufacturing. The literature will identify and discuss the research papers by some of the phases of remanufacturing. Most of the recent reviews in the remanufacturing field are focused on a particular domain, such as barriers in automotive industry [20], lifecycle strategies to enhance remanufacturing [21], assembly management in remanufacturing [22], applicability of remanufacturing for marine or offshore components [23], decision making in remanufacturing [24], and scheduling in remanufacturing [25]. Thus, a recent holistic review is missing, and this research will fill that gap. Moreover, most of the reviews are qualitative, and only a few of them are quantitative. In this work, both the qualitative and quantitative analyses are conducted. The main aim of this paper is to provide an in-depth insight into remanufacturing, discuss its various facets, as well as identifying the various solution methodologies applied in this domain. The motivation of this review paper is to neatly review the recent progress in remanufacturing and to identify areas that have not been researched or explored thoroughly, so the readers will acquire a piece of good knowledge about this important area. This research, therefore, aims to thoroughly analyze the existing remanufacturing challenges and opportunities. The following key research questions (RQs) are formulated to guide the review in achieving the mentioned objectives:

RQ1: How is remanufacturing different from allied concepts such as recycling, reuse, reconditioning, repair, and so on? 
RQ2: What are the major phases involved in remanufacturing and solution methods employed by researchers for remanufacturing?

RQ3: What are the barriers and challenges in adopting remanufacturing?

RQ4: What are the research trends in the remanufacturing domain during the last decade and knowledge gaps for future research?

The remainder of this paper is organized as follows. Section 2 reports the methodology employed for this review. Concepts and phases of remanufacturing are presented in Section 3. Section 4 discusses the solution methodologies implemented in the remanufacturing domain by researchers, and Section 5 examines the barriers in espousing remanufacturing. Section 6 presents the results from a bibliometric analysis perspective. Section 7 presents the discussion about the research. Lastly, Section 8 summarizes the conclusions, limitations of this study, and future research directions.

\section{Research Methodology}

In this research, the remanufacturing field is analyzed both qualitatively as well as quantitatively. Major focus is placed on research work during the last decade so as to gain an understanding of recent research patterns and directions. For qualitative analysis, research works by various authors are reviewed, classified into various categories, and their major findings are presented. Qualitative analysis is required by researchers to grasp an idea about the recent advances in the field and how people are approaching different research directions within a domain. Hence, qualitative analysis is also conducted for remanufacturing research. In qualitative analysis, various phases of remanufacturing are discussed and how the researchers are investigating these fields. Moreover, the solution methodologies employed by researchers for remanufacturing are also explored.

For quantitative analysis of remanufacturing research, a brief bibliometric analysis is conducted. Through bibliometric analysis, it is easier to realize more about factors, such as journals that are more prominent in this field, dominant authors and institutes working in this area, and so on. Through this methodology, the above-mentioned RQs are addressed. Bibliometric analysis is a research field that analyses published articles, citations, and their sources of information. These types of research enable researchers and specialists to have a better perception of a specific research field by considering research articles, journals, authors, institutions, and countries. This provides researchers to have a general notion of the research field. In the literature, many researchers have published bibliometric analysisbased research in several fields [26-41]. However, in the remanufacturing domain, there is no general research that provides any kind of bibliometric study. Therefore, through bibliometric analysis, the aim is to provide an overall picture of remanufacturing research from the beginning of this research area, which was reported nearly 38 years ago. Based on the information gathered from the Web of Science website (WOS), an overview of the most productive and influential studies in the concerning research area will be presented.

In order to be informative and neutral with the information, the search process is based on the results found only in the WOS database, although there are other databases available that are not considered, such as SCOPUS and Google Scholar. Most of the time, data collected from different databases have overlapping [42]; thus, to avoid redundancy, the research was conducted on the WOS database only. Moreover, it includes the most influential journals in most of the scientific fields $[43,44]$. Moreover, the WOS provides a good classification that facilitates the analysis of research articles easily. This research is considering the remanufacturing research work, so these two keywords-"remanufacturing" or "remanufacture"-were used to perform the search process in the "Topic" search section. This search collected all the articles belonging to the "remanufacturing" field. The data-collection process was completed in February 2021. There were 3545 papers under the topic of "remanufacturing" or "remanufacture," considering that this number includes all the types of documents covered by the WOS, which includes 13 different types of publications, including journal articles, proceedings papers, books, notes, comments, reviews, and editorial material. To focus on the main articles, this information has been filtered by only 
looking for journal articles and reviews. This is because most of the quality research works are reported in the journal articles by researchers that compare and summarize original ideas. The results were filtered accordingly, which reduced the total number of publications to 2525 papers. Most of these publications came from the last decade. The various results obtained from this methodology are presented and discussed in Section 6. Preferred Reporting Items for Systematic Reviews and Meta-Analyses (PRISMA) flowchart was chosen to help in visualizing the process of selecting articles (see Figure 1$)$. It included the articles identified in the initial search $(n=3545)$ and the articles after the screening $(n=2525)$. This large number of articles is utilized for quantitative analysis only (bibliometric); not all articles are included in qualitative analysis.

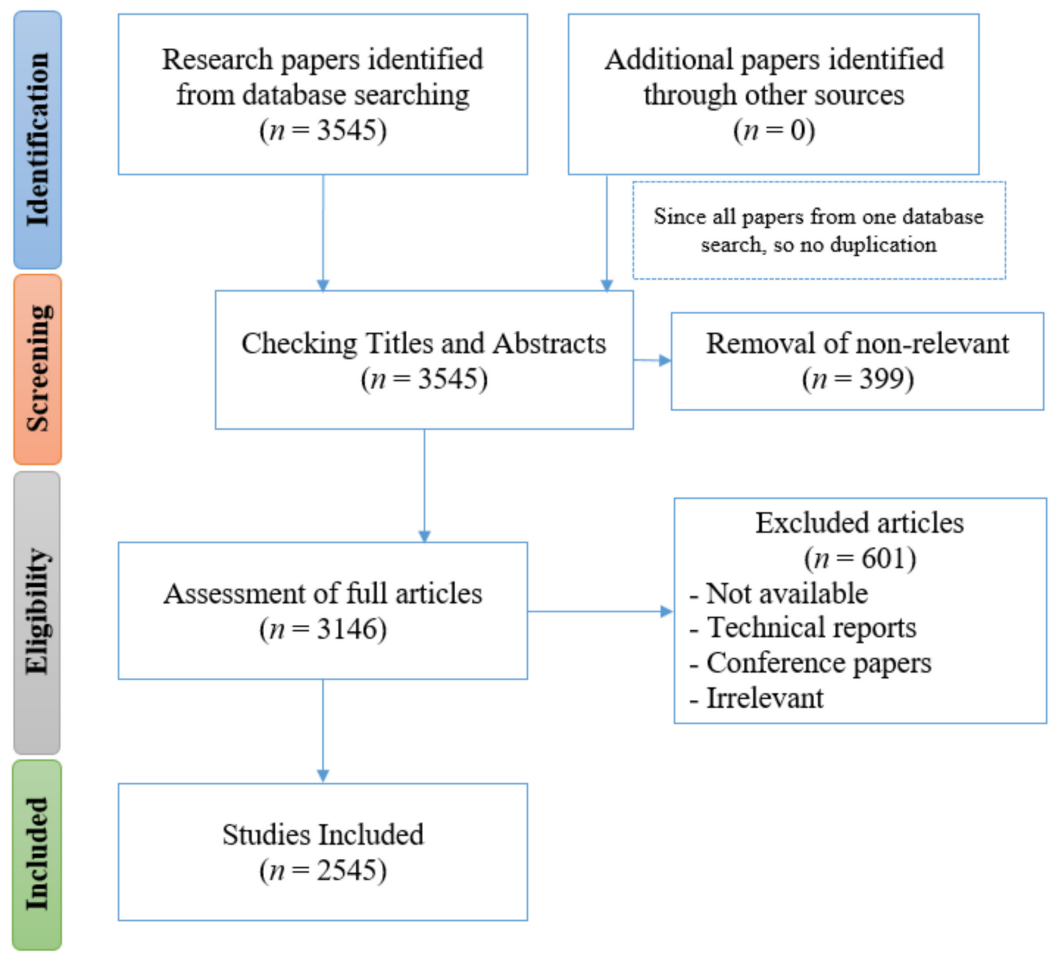

Figure 1. PRISMA flowchart for quantitative analysis literature.

\section{Concept and Phases of Remanufacturing}

Though the concept of remanufacturing has been known for some time, still many people confuse it with other closely related concepts such as reconditioning, recycling, reuse, and so on. All of these processes are very closely connected to each other, but there is a differentiation between them that is important to understand. Various researchers defined this term in their own ways, and some of them are listed below.

Haynsworth and Lyons [45], in 1987, defined remanufacturing as "The process of bringing a product to like-new condition through replacing and rebuilding component parts". Via case study, it was shown that one of the essential factors that practitioners use to separate remanufacturing from repair and reconditioning is to bring remanufactured goods to at least original requirements. The definition has a flaw because it does not provide the consumer with a way of quickly identifying that remanufactured goods are of better quality than restored and reconditioned alternatives or that remanufactured products are of comparable quality to new alternatives.

Amezquita et al. [46], in 1995, described remanufacturing as "The process of reusing, reconditioning, and replacing parts to bring a product to a similar new condition". Conversely, in the same research, reconditioning was defined as a process that differs from remanufacturing and produces goods that are lower in quality than those produced by 
remanufacturing. Therefore, the above definition does not clearly distinguish between remanufacturing and reconditioning.

Ijomah [47], in 2002, defined remanufacturing as "a method of returning a used product from the customer's perspective to at least original equipment manufacturer (OEM) performance specifications and giving the resulting product a guarantee that is at least equal to that of a newly produced equivalent." This definition seems to be more complete than the previous ones. The authors went further ahead to define repair and reconditioning also. They point out that repair is simply the process of correcting a particular defect or breakdown in a product, and that the warranty only applies to the parts that have been replaced. Although, reconditioning is the process of returning end-of-life or used product to a suitable performance condition that is less than the original OEM specification, and its warranty is limited to the key worn components. Figure 2 below shows the differentiation between remanufacturing, reconditioning, and repair. Furthermore, Table 1 presents the various product recovery techniques [48] and depicts how they differ from each other.

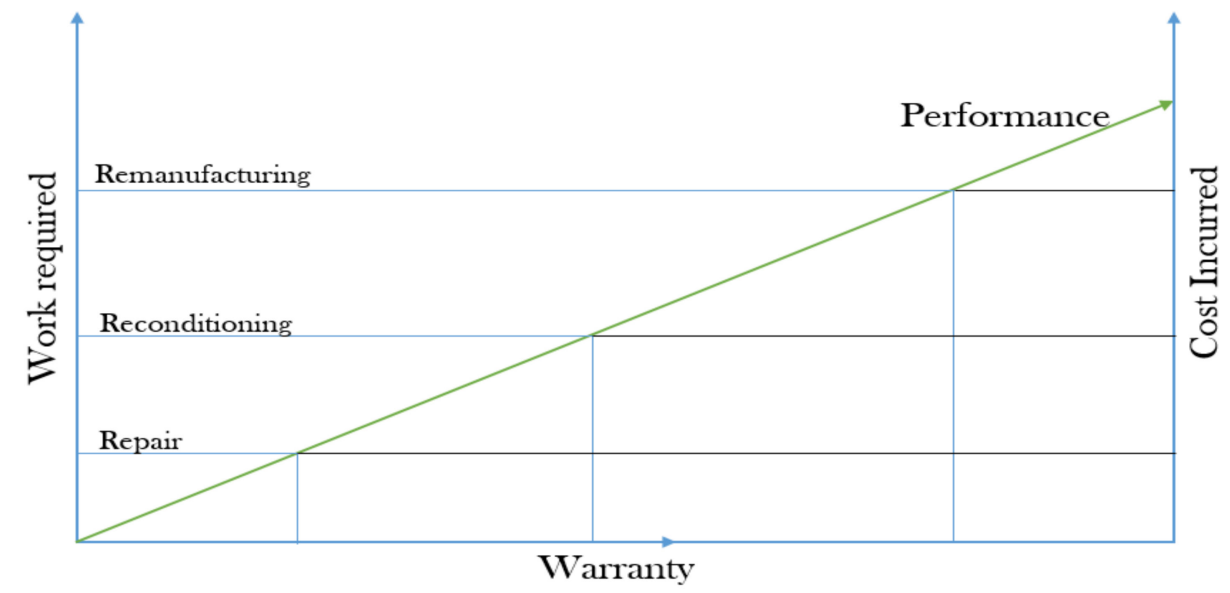

Figure 2. A figure illustrating the difference between remanufacturing, reconditioning, and repair [47].

Table 1. Product recovery techniques [48].

\begin{tabular}{cccccccc}
\hline Technique & Disassembly & $\begin{array}{c}\text { Quantity } \\
\text { Recovered }\end{array}$ & $\begin{array}{c}\text { Quality (vs. } \\
\text { New Good) }\end{array}$ & $\begin{array}{c}\text { Technological } \\
\text { Upgradation }\end{array}$ & Service Life & Warranty & $\begin{array}{c}\text { Embodied } \\
\text { Value Retained }\end{array}$ \\
\hline Reuse & Limited & Fully/Partially & Low & No & Low & No & Yes \\
Repair & Limited & Fully/Partially & Inferior & No & Low & Yes & Yes \\
Refurbish & Limited & Fully/Partially & Low & Yes & Extended & Yes & Yes \\
Cannibalization & Selective & Selective & Moderate & No & - & - & Lost \\
Recycle & Selective & Selective & Depend & No & - & - & Lost \\
Reconditioning & Selective & Selective & Inferior & No & Extended & No & Yes \\
Remanufacture & Complete & Very High & Very High & Yes & High & Yes & Yes \\
\hline
\end{tabular}

Remanufacturing is described as a particular industrial process of disassembling, cleaning, inspecting, repairing, replacing, and reassembling the components of a part or product in order to return it to "as-new" condition, according to Nasr and Thurston [49].

The World Trade Organization (WTO), in 2009 [50], has determined remanufactured goods to be, " ... non-agricultural goods that are entirely or partially comprised of parts that (i) have been obtained from the disassembly of used goods; and (ii) have been processed, cleaned, inspected, and tested to the extent necessary to ensure they have been restored to original working condition or better; and for which the remanufacturer has issued a warranty".

The United States International Trade Commission (USITC), in 2012 [51], has defined remanufacturing as: "An industrial process that takes place in an industrial setting that restores the end-of-life goods to original working condition or better. Firms that provide 
remanufacturing services to restore end-of-life goods to the original working condition are considered producers of remanufactured goods".

In 2016, six international automotive remanufacturing associations have reached an international agreement on a remanufacturing definition (specific to the automotive sector) [52], and defined it as follows: "Remanufacturing is a standardized industrial process by which cores are returned to same as new, or better, condition and performance. The process is in line with specific technical specifications, including engineering, quality, and testing standards. The process yields fully warranted products. A core is a previously sold, worn or non-functional product or part intended for the remanufacturing process. During reverse- logistics, a core is protected, handled, and identified for remanufacturing to avoid damage and to preserve its value. A core is not waste or scrap and is not intended to be reused before remanufacturing".

Thus, it can be said that remanufacturing is defined by researchers and organizations according to their domain and application. The exact method and operation carried out by remanufacturers vary depending on the product type, although the major concepts and steps of remanufacturing remain the same for all sectors with slight variations in implementation.

First, the major phases of conventional manufacturing are shown in Figure 2, so one can easily see the difference between conventional manufacturing and the remanufacturing process. As depicted in Figure 3, conventional manufacturing is a linear process.

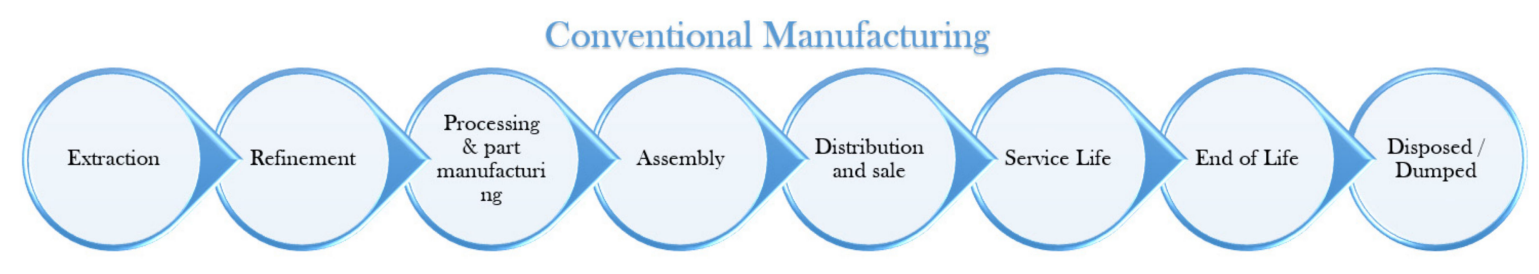

Figure 3. Major phases of conventional manufacturing (modified from [53]).

The life cycle of a remanufactured transmission commences at the conclusion of the life of another transmission. From the EOL stage of manufacturing, the remanufacturing phase starts. Figure 4 below shows the major steps involved in the remanufacturing process. As depicted in Figure 4, remanufacturing is a circular process and thus helps in resource saving. A brief definition of these steps is provided subsequent to the figure.

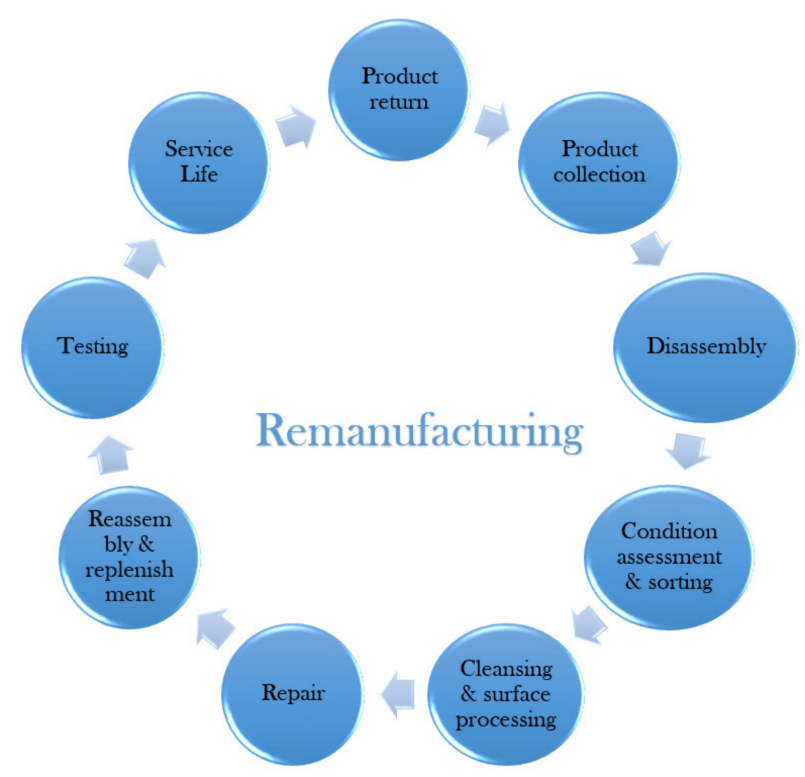

Figure 4. Major steps involved in remanufacturing (modified from [53]). 
Product collection: After the end of life step in the conventional manufacturing process, the product (or core) is acquired for remanufacturing. It is a very important phase, and a proper collection system should be developed for an efficient remanufacturing process [54] Disassembly: Then, the failed product is completely dismantled at the remanufacturing facility. Disassembly planning is vital since it is a time-consuming process if the product is not designed properly for disassembly [55].

Condition assessment and sorting: To evaluate the condition of the dismantled product, each piece is examined. The pieces are then divided into three categories: functional, repairable, and unusable [56].

Cleansing and surface processing: The pieces that are functional and repairable are then thoroughly washed and cleaned. In this step, the individual component is reconditioned [57].

Repair: Repairs and upgrades to the parts are carried out using a variety of processes that depend on the experience of the workforce as well as advanced manufacturing technology [1].

Reassembly and replenishment: The parts and components that have been gathered, cleaned, restored, and processed are used to reassemble an entirely new product. Any new parts that are needed are also integrated [1].

Testing: The remanufactured product's output is assessed against the OEM's (Original Equipment Manufacturer) requirements for that particular model. Especially nondestructive testing methods are employed [58].

Service life: The product is shipped and goes into operation for its new service life. The warranty is provided based on the life cycle assessment made for the product [59].

Product return: When a product hits the end of its useful life, it should be returned to the remanufacturing process to see whether it can be remanufactured again. Thus, in this way, it is a perpetual process and saves a lot of time and energy [1].

Apart from the aforementioned steps, with advances in the remanufacturing area, more emphasis is now being placed on the design and development stage. Some researchers consider design and development as the first phase, and it aims at facilitating the remanufacturing process by product design so that the coming phases are carried out smoother [13]. The next sub-section discusses some of the research works on the design and development of the remanufacturing domain.

\subsection{Design and Development}

It is critical to recognize the steps involved in remanufacturing procedures before designing goods for successful remanufacturing. The items intended for remanufacturing must be adaptable to all stages of the remanufacturing process rather than only some phases. Many factors must be addressed when designing for remanufacturing, including ease of disassembly, sorting, cleaning, refurbishment, reassembly, and testing [60]. However, many goods are not designed to be remanufactured [61]. The purpose of remanufacture design is to make products and parts easier to reuse. The modular design of items is a critical technical issue in bringing this concept to life [62]. In fact, design for remanufacturing (Dfrem) includes all strategies, namely design for assembly, design for disassembly, design for recycling, design for modularity, and design for environment. These strategies have several benefits; however, it is difficult for a designer to fulfill all of these, since many constraints exist, such as material, technology, cost, time to market, and so on [63]. Some researchers also proposed Dfrem guidelines $[64,65]$. Hence, Dfrem is beneficial in terms of cost and time saving, and it has a potential for reducing the time and expenses of the remanufacturing process. However, there are challenges identified by researchers, and major challenges are information sharing and lack of communication [66,67]. Most of the manufacturing firms do not conduct remanufacturing and have contracted remanufacturers. Thus, a proper communication between the design team and the remanufacturer is vital [66]. One of the researchers mentioned that one key criterion in remanufacturing is that the parts to be replaced must be able to endure being inspected, disassembled, cleaned, reprocessed, 
reassembled, and tested multiple times [68]. Further, they created a RemPro matrix, which shows designers which product features make each remanufacturing process step easier. It was further augmented by Allwood et al. by adding design guidelines [69].

Regarding design and development, many studies in the literature, such as Cheng et al. [70], have discussed the remanufacturing phases, where a heavy-duty machine tool method was proposed for green remanufacturing. The axiomatic design was used along with an algorithm based on atomic theory utilization in the study. The method was tested on a milling machine and proved to support design efficiency. In other studies by Zhang et al. and Fang et al. [11,12], a review was provided on some of the top remanufacturing research issues; they used them to determine the design factors that influence the remanufacturing process, especially at the EOL (end of life) phase. Using the Taguchi method, Sitek et al. [71] used three different techniques in the remanufacturing design of BGA component balls. The quality and parameters of the balls were assessed afterward, and their shapes and sizes were compared. The study found all three techniques suitable for BGA components' ball remanufacturing, quality-wise. Gong et al. [72] found the optimal design schemed for remanufacturing by presenting a multi-attribute decision-making method. Using an assembly machine to test their method, the results proved the proposed method effective and reliable in decision-making design schemes in remanufacturing. Similarly, Huang et al. [73] presented a design method for the remanufacturing of incomplete information of used parts using 3D scanning and the geometric information recovery model. After the remanufacturing process, the same turbine blades were tested for accuracy and error analysis, and the results proved the method's feasibility. Ramachandran et al. [74] used the Taguchi optimization method to find the effective design parameters for piston reuse and remanufacture. They carried out the design and analysis using SolidWorks. After implementation, the results showed that the new piston created was similar to the original one. Den Hollander et al. [8] discussed how products could be designed so that they can be reused. They provided guiding principles, design strategies, and methods for product design in a circular economy, where no product goes to waste but instead is reused, using consumer products as their focal point. Um et al. [75] developed an initiative system for an efficient development method for remanufacturing using a ubiquitous product recovery management system. The method was tested on the remanufacturing of a starter motor in a construction machine, and the results showed that the method can be used for general and specific products as well. Zhang et al. [76] conducted a study, and the aim was to understand and discuss the design concept of remanufacturing as well as the different methods and tools in this area. They also discussed the key issues and the associated problems. Since the design for remanufacturing is a growing area, the results reported that there is a need of tool and method development for the different product groups according to specific guidelines. Ke et al. [77] proposed an intelligent design for a remanufacturing system based on vector space model (VSM) and case-based reasoning (CBR). VSM was utilized to extract customer demand data features from mass customer demand data, which included remanufacturing data, and the K-means method is used to identify customer demand data features, allowing design for remanufacturing targets to be extracted. Clutch remanufacturing, as case studies, was presented. The results showed that the approach can produce a design scheme that is precise enough to meet the needs of the consumer.

In order to decide whether remanufacturing can be carried out, assessment methods need to be conducted. Fang et al. [12] presented an assessment framework for product remanufacturability based on design information with the use of CAD models. In their model, they focused on the evaluation of two remanufacturing aspects; part disassemblability and part recoverability using four correlated numerical metrics; disassembly complexity, fastener accessibility, disassemblability, and recoverability. An automotive alternator SolidWorks CAD model was used to validate the system. The results showed that design information proves to support the re-manufacturability assessment of a product design and makes it more effective. Joshii et al. [78] suggested an advanced ARTODTO (advanced remanufacturing-to-order and disassembly-to-order) system to evaluate the effects of product designs on recovery operations for EOL products. By the use of decision-making techniques and linear physical programming, the model is created and implemented on a 
disassembled EOL cell phone. The study concluded that a product's design is an important part of product recovery, and considering recovery options initially during the design phase of a product can reduce recovery costs. The proposed method can efficiently determine the best possible product design for product recovery.

Some studies turned to green remanufacturing, which is a type of recycling that adapts to ecological and economical requirements. For example, Smith et al. [79] aimed to create a selective parallel disassembly planning method for green design. The study used a modular design theory and the results showed that the method can be used for many design types as well as reducing disassembly steps, disassembly time, and energy use. To improve green manufacturing capacity of heavy-duty machine tools, Dong et al. [80] used axiomatic design along with particle swarm algorithm to find the best design method for these tools. The study extended the design process into many different domains, including customer domain and process domain. Similarly, a heavy-duty gantry milling machine was used to verify the method used by Cheng et al. [70] for green manufacturing of heavy-duty machine tools. Their module contributed to design efficiency support in remanufacturing. Hence, it can be said that much effort can be reduced if the design of remanufacturing is kept in mind from the starting. It will ease the work at later stages. Hence, this research area needs to be explored more.

\subsection{Disassembly}

In this phase, the unit is fully disassembled down to the single component level. In this process, the product to be remanufactured would be disassembled into its modules, which are further disassembled into the individual components [81]. Researchers have proposed many suggestions. For example, Huang et al. [82] suggested a metal magnetic memory (MMM) technique to evaluate disassembly damages under contact pressure. The results showed various damage forms on the disassembly interface. In the study by Mesa et al. [83], a method for mechanical joining was created based on assembly and disassembly principles. They found the method to be useful in the improvement of such tasks, including component addition, exchange, and removal between manufacturers and suppliers. Smith and Hung [79] aimed to create a selective parallel disassembly planning method for green design. The study used a modular design theory, and the results showed that the method can be used for many design types as well as reducing disassembly steps, disassembly time, and energy use. Aiming to investigate the disassemble-to-order problem, Inderfurth et al. [84] used real data to model random yields in manufacturing. Their results showed the lowering of costs of penalties and obtaining preferable results. Hu et al. [85] presented a model that estimates disassembly time automatically. In the study, SolidWorks in visual C\# programming was used for the implementation of the algorithm and method. They presented four case studies to test their method. In a study by Abdullah et al. [86], a reverse assembly strategy for disassembly was presented. The study showed that using a standard operating procedure is more relevant than random methods.

In most cases, remanufacturing involves disassembly of all component parts for inspection and cleaning; however, in some cases (such as digital printers), only disassembly down to the module level may be necessary. This is particularly true when the module has been designed for remanufacturing, in this case the module's planned technical life may be longer than the one shown by the product's design [18]. After collection, disassembly is the main step in the remanufacturing process; therefore, efficient disassembly planning methods are required to reduce the time spent and the damage incurred to the product. 


\subsection{Condition Assessment and Sorting}

During this stage, used products are inspected for their quality conditions in order to assess their re-manufacturability status [81]. Other studies have focused on the inspection phase of remanufacturing. For instance, Ridley et al. [87] discussed factors that affect decisions concerning pre-processing inspection. These are aimed at the overall remanufacturing process and pre-processing inspection of cores to convey that automotive remanufacturing sectors may save up to $20 \%$ of their time by properly inspecting cores preceding processing. Their results were presented in a research conducted in an industrial manufacturing facility on the remanufacturing of returned products. Suhariyonto et al. [88] proposed a multi-life cycle assessment for products during remanufacturing. By the use of a continuous-time Markov chain (CTMC) and the matrix-geometric method, Farahani et al. [89] developed an optimal decision-making model that considers the quality of returns and recoverable product capacity. They also developed an optimization model to initiate optimal quality levels of product returns and inventory for a general remanufacturing facility. The study found that variations in return arrivals and the quality of the recovered product affect customer's order completion for recovery of smaller product inventories. Paterson et al. [90] presented a tool that helps to determine the status of a product that has undergone an end-of-life recovery strategy, whether it is a recycled, remanufactured, reconditioned, repaired, or re-used product. The tool showed many benefits, such as being able to identify product status and check whether the remanufactured product was labeled correctly. To provide optimal recovery options for EOL products in remanufacturing, Jiang et al. [91] presented a multi-objective optimization method. A used lathe was used as an example to validate the method. The results proved the method effective in the value recovery of EOL products. Liu et al. and Lu et al. $[92,93]$ both discussed fatigue damage assessment methods that could be used during remanufacturing. Similarly, Chen et al. [94] performed remanufacturing of EA4T steel axles and investigated the microstructure and fatigue crack growth. The results supported the theoretical and experimental basis for the remanufacturing and fatigue fracture mechanism of EA4T steel axles. Errington and Childe [95] presented a casestudy-based research for the inspection process in remanufacturing for both electronics as well as mechanical products. A model was developed and tested to provide a better understanding of the remanufacturing inspection procedures currently being used. Lahrour et al. [96] focused on products and components with characteristics that are suitable with additive remanufacturing. They presented key steps that will help remanufacturers decide on product re-manufacturability and provided assessment feedback that might improve the design and manufacturing process. Jiang et al. [97] provided a prediction approach for the evaluation of used parts in remanufacturing. Their approach was validated with the use of a TPX6113 boring machine as an example, and the method provided a new perspective on used parts evaluation. Wang et al. [98] proposed a mechanism for the modification coatings for damaged equipment that will be remanufactured. Intelligent coatings were designed and developed and were successfully applied to critical friction components, such as the spindle of large centrifugal compressors, engine cylinder piston components, and driver gear pairs. This step is very crucial in remanufacturing since good experience as well as methodology is required to assess the current condition of the components, and what further processing is required is decided based on this step.

\section{EOL Products Decision Making}

Decision-making in remanufacturing is a model by which manufacturers can conclude which decisions should be made. Yang et al. [99] provided a decision support tool for EOL strategy planning with the use of remanufacturing. The method includes a list of proposed methods to evaluate the remanufacturing ability of a product and its components. An optimization model was created to determine a set of optimal strategies along with a genetic algorithm to calculate these strategies. In the study, two types of desktop phones were used to implement the proposed method. The results showed significant perceptions of EOL decisions. Favi et al. [100] presented an approach to help designers in the evaluation 
and improvement of product EOL performance. Designers can benefit from the proposed method in the modification of the product structure for the reuse and remanufacture of components along with material recycling. The approach was validated by a case study in helping designers during the redesign phase of products to reduce the number of materials and therefore reducing industrial wastes sent to landfills. Barkmeyer et al. [101] proposed a procedure for the assessment of end-of-life strategies to support decisionmaking within product development. Pneumatic cylinders were used as a case study to illustrate the procedure.

\subsection{Cleansing and Surface Processing}

Cleansing generally involves de-greasing, de-oiling, de-rusting, and removing old paint from the components. Regarding the cleaning phase, Esquer et al. [102] presented a cleaning program for a manufacturing facility for the remanufacturing of air compressors. The program consisted of prevention, elimination, and reduction of risks. The program created found areas of opportunity to improve in equipment, material, and methods in the company. Zhang et al. [76] carried out an experiment to clean carbon deposition, which is very difficult to be removed during the remanufacturing process. They used a molten salt formula, and the results showed that the cleaning process works best when the mass fraction of $\mathrm{NaOH}$ is $30 \%$. Similarly, aiming to clean surface paint, Qin et al. [103] used a high-temperature decomposition process. They concluded that the process is an effective method for removing paint from steel metal used parts. However, it was found ineffective in carburizing and quenching steel. In a study by Li et al. [104], engines were cleaned by two different methods and compared. The results showed that SCCO2 cleaning is a manageable approach and has minimal impact on surface hardness, while thermal pre-treatment can drastically decrease the hardness.

\subsection{Repair}

In a study by Feng et al. [105], an approach for a damaged part in the field of remanufacturing repair was proposed. By the use of 3D metal printing instead of traditional mechanical repair, a more practical and complete framework is created to tackle repair issues. A damaged gear was used to validate the experiments, and the method is proven to be effective, robust, and highly automated. Studies benefit supply chains as they found that small recoverable product inventories have variations in return arrivals and quality of recoverable products, which in turn affects the completion of customer's orders. Liu et al. [106] constructed a model on a remanufactured crankshaft taking assembly operation and part attributes as input and assembly quality as the output. Afterward, they created a transfer function for assembly quality, which was then used to characterize the coupling mechanism of assembly error. The results of the case study show that the methods can improve the reassembly precision. In another study by Liu et al. [107], they provided a review on IMAC (in situ monitoring and adaptive control) research, which is regarded as an effective method to overcome challenges such as having the ability to turn worn-out or damaged products into a workable condition to achieve better performance. This review is the first to focus on IMAC technology of LCR (laser cladding remanufacturing) in the remanufacturing industry and serves to help researchers understand what has been investigated and the research gaps that need to be further investigated. Further, Liu et al. [108] aimed to discover surface defects of rotational parts using a new method based on improved two-dimensional reciprocal cross-entropy. The effectiveness of the method was tested on a case study of rollers and proved to be the best out of the other three methods in segmentation, accuracy, and noise immunity. Kawasaki et al. [109] presented a method for the remanufacturing of pinion and large-sized skew bevel gears. They used a computer numerical control (CNC) machine and provided a mathematical model, which, in result, proved that there was a good agreement between them. A research work was oriented toward machine tool spindle and the analysis of repaired spindle function. This paper analyzes the spindle through static and dynamic performance before re-manufacturing. In 
order to make reasonable arrangements for the parameters of the spindle, the accuracy level is too high to avoid, which causes costs to the parts' remanufacturing. To provide the new product with quality and warranty, an appropriate repair process has to be implemented.

\subsection{Reassembly}

The reassembly stages involve tools for the reassembly of the components into remanufactured products. In a study by Shen et al. [110], a new quality control assembly method based on the Jacobian-Torsor model for remanufacturing assembly was used to produce and analyze six different batches of remanufactured engines. This new standard optimized the traditional one and proved to be a suitable engine assembly. Yu et al. [111] considered a remanufacturing scheduling problem to determine the job sequence on the parallel disassembly workstations, the sequence of the jobs on each workstation of job-shop-type reprocessing shop, and the allocation/sequence on the parallel reassembly workstations. They developed two types of solution algorithms to solve the disassembly, reprocessing and reassembly scheduling sub-problems. One algorithm solves the problems separately and at the same time as well. The results showed that the integrated algorithms significantly outperform the intuitive decomposed ones. In another study by Ge et al. [112], a reassembly classification selection method based on the Markov chain was proposed as an effective method to improve the utilization of used parts in remanufacturing. The method was executed on a remanufactured crankshaft to show its feasibility.

To overcome the challenge of unpredictable supply of inventory for future reassembly purposes, an optimization model for simultaneous reassembly and procurement planning to determine the type and number of parts that should be reassembled and procured was created by [112]. Marketing demand was considered along with recycling benefits, and a smartphone was used as an example of the method.

Different reassembly techniques may be used for various industries. In the case of medical devices, each disassembled component has a unique serial number, and it must be reassembled into the very same remanufactured product; this is in contrast to other industries, where decommissioned parts can be placed in a generic inventory and used as required in the remanufacturing of totally distinct product units [18]. Reassembly is same as assembly in the traditional way of manufacturing; thus, a product has to be designed for ease of assembly to save cost and efforts at this stage.

\subsection{Testing}

After reassembly, quality check is required to examine the proper functionality of the remanufactured product. The remanufactured transmission output is measured and evaluated against the requirements set by the OEM of the particular model [59]. Williams et al. [113] discussed the remanufacturing benefits and testing of the electronic control unit of automotive. A testing strategy was presented and verified. Changliang et al. [114] presented various types of non-destructive testing (NDT) methods for old automotive engine testing for remanufacturing. Different types of NDT methods reported for this purpose are ultrasonic testing, metal magnetic memory testing, and eddy current testing. Tant et al. [115] proposed a concept of design for testing for improving remanufacturability. It was proposed that NDT methods are more suitable for remanufacturing because these methods do not alter the component at the microstructural level. The remanufacturing process claims to provide warranty and quality similar to the new product; hence, rigorous testing methods need to be employed to ensure the product quality.

\section{Solution Methodologies}

There are several methods the author proposes for solving the problems of remanufacturing, and they depend on the availability and plan of the solution; authors have various opinions on their types of solution. The solution techniques are classified based on their methodology such as optimization-based methods, simulation-based methods, 
case-study-based research, decision-making-based methods, uncertainties models, and other techniques.

\subsection{Optimization Techniques-Based Methods}

Some researchers used optimization techniques. For instance, the study by Gao et al. [116] focused on deterministic EOL product recovery evaluation and optimization, while Farahani et al. [89] developed an optimal decision-making model that considers the quality of returns and recoverable product capacity. They also developed an optimization model to initiate optimal quality levels of product returns and inventory for a general remanufacturing facility. Jiang et al. [91] introduced a multi-objective optimization method for the value recovery of EOL products. It was used to obtain the optimal value recovery options for used components and to recover valuable components from EOL products. Shi et al. [117] proposed a new environment-aware scheduling model for the remanufacturing system. An improved flower pollination algorithm with a new two-dimensional representation scheme was employed, and the results obtained were compared against six baseline algorithms (different variants of genetic algorithm, simulated annealing, and particle swarm optimization) for scheduling problems. It was reported that the proposed algorithm performed better than the other six algorithms for remanufacturing system scheduling problems.

\subsection{Simulation-Based Methods}

Studies that used software in their methods are Fang et al. [12], who presented a product remanufacturability assessment model using CAD and SolidWorks, and Dung et al. [118], who also used CAD to develop a system that can process digitized data for repairing processes. Some combined optimization techniques and software. Others, such as [71-73], combined optimization techniques and the use of machinery.

\subsection{Experimental or Case-Study-Based Methods}

Validating work is an important process with which to prove the efficiency of the developed methodologies and techniques, and from these perspectives, researchers have validated their works using some experimental methods or case-studies-based methods.

Some studies carried out experimental-based methods, such as a study by Feng et al. [105], where a repair volume extraction method that integrates surface reconstruction and repair volume extraction was proposed. The proposed method was validated by two experiments designed to extract the repair volume of a damaged gear with both planar and non-planar broken surfaces and is proven to be effective, robust, and highly automated. Zhang et al. [11] proposed a two-phase QFD (quality function deployment) model by reusing failure modes feedback from EOL products. The comprehensive list of design factors of products is developed by literature review, which includes engineering characteristics and DfRem guidelines. A case study of the automotive engine crankshaft validates the feasibility of the method proposed. The main contribution of the proposed method lies in finding the DfRem improvement direction accurately based on the failure modes.

\subsubsection{Case Studies at the Component Level}

To validate their proposed work and studies, authors need to experiment and implement on case studies. These studies may include individual parts. Zhang et al. [119] presented the effectiveness of the Gauss-Newton iterative method on the remanufacturing assembly process of a cylinder head. Huang et al. and Mesa et al. [82,83] applied their methods on fit joints and mechanical joints, respectively. As mentioned earlier, Joshi et al. [78] utilized the ARTODTO system, which is a system that receives sensors and RFID (radio frequency identification) tags for embedded EOL products. They implemented it on a cellphone to determine the best product designs for product recovery. Likewise, Huang et al. [73] proposed a remanufacturing scheme design method on turbine blades. Chen et al. [94] experimented with the microstructure and fatigue fracture behavior of EA4T 
steel with laser cladding remanufacturing. Esquer et al. [102] conducted a cleaning program for the remanufacturing of air compressors in a manufacturing facility. Shi et al. [120] presented a re-manufacturability evaluation method for the remanufacturing process of disassembly, cleaning, testing, repairing, and assembly and tested it on a WD615.87 diesel engine. Dung et al. [118] created a framework for the detection of automatic weld beads on free-form surface parts that are used in remanufacturing processes. In a research study, the remanufacturing process of injectors was discussed. They defined a control methodology of the injector that helps to prevent defective injector bodies from entering into the remanufacturing process [121]. In another study, researchers utilized an optimization model for determining the optimal EOL strategies on two desktop phones along with their components [99].

\subsubsection{Assembly and Sub-Assembly Level}

Others implemented on combined parts. For example, Gao et al. [116] and Serb et al. [122] employed their methods on motors. Fang et al. [12] presented a product re-manufacturability assessment model on an automotive alternator. Ridley et al. [87] aimed at the overall remanufacturing process and pre-processing inspection of cores to convey that automotive remanufacturing sectors may save up to $20 \%$ of their time by properly inspecting cores' preceding processing. Their results were presented in a research conducted in an industrial manufacturing facility on the remanufacturing of returned products. Sitek et al. [71] as well as Ramachandran and Agarwal [74] both utilized the Taguchi method on a BGA (ball grid array) ball grid and scrapped piston, respectively, to prove its effectiveness during the remanufacturing process. Dong et al. [80] studied the evaluation of remaining fatigue life of a remanufacturing truck crane.

\subsubsection{Product Level}

Machines are also utilized in these studies, such as that conducted by Cheng et al. [70], who implemented a novel modularization method on a heavy-duty gantry milling machine remanufacturing. Additionally, Du et al. [123] established an evaluation criteria system for heavy-duty machine tool remanufacturing such as a heavy-duty horizontal lathe. Moreover, researchers used a lathe machine to obtain the optimal value recovery options for EOL products [91]. Lu et al. [93] presented their damage mechanism and evaluation model on large centrifugal compressor impellers. Their discoveries show that the model is successful in the analysis and assessment of large centrifugal compressor impellers before the remanufacturing process. In another study, researchers utilized impellers to present a life cycle assessment method comparing the environmental impacts of different impeller manufacturing and remanufacturing methods [124]. Jiang et al. [97] proposed a method that provides a new perspective on implementing used parts evaluation with a used TPX6113 boring machine as an example of their approach. Nassehi and Colledani [125], demonstrated their proposed method on a test case with an automotive part remanufacturer. It is noticed that the more we go in the production area, the more do the authors face complexity in applying their ideas as case studies. This is due to the major role of monitoring and controlling of the items in the products.

\subsection{Decision-Making-Models-Based Methods}

The literature also consisted of research works that used decision-making models in the remanufacturing process.

One research study provided a decision-making methodology for inspection along with a tool for cost assessment in their study [87]. Rizova et al. [24] provided a systematic review for the decision-making models' research in remanufacturing. They classified decisions in remanufacturing into three categories, namely operational, strategical, and tactical. The assessment showed that $48 \%$ of the studies focused on strategic-level decisions, $34 \%$ on tactical-level decisions, only $5 \%$ on operational-level decisions, and the rest on 
combinations. It was also reported that $60 \%$ of the researchers proposed mathematical models. Moreover, uncertainties were discussed in $36 \%$ of the studies.

In another study, a multi-objective decision-making approach was discussed for EOL product recovery [116]. Some researchers focused on how remanufacturers can make decisions on products' re-manufacturability. An artificial bee colony (ABC) algorithm was considered in the study to find the best EOL options in product recovery [96].

Another study aimed to propose a decision-making method of heavy-duty machine tool remanufacturing based on the analytic hierarchy process (AHP)-entropy weight and extension theory [123]. To accurately select the optimal design remanufacturing scheme, [72] presented a non-empirical hybrid multi-attribute decision-making method.

Nassehi and Colledani [125] analyzed the relationship of customer behavior on remanufacturing decisions. Joshi et al. [78] proposed a decision-making approach for remanufacturing based on the fuzzy analytical hierarchy process (AHP) to evaluate remanufacturability and product design.

To solve the uncertainty problems in remanufacturing, a scheme design method was provided based on the incomplete reconstruction of used part information [73]. In their research, den Hollander et al. [8] discussed principles and methods required for circular product design in remanufacturing. Suhariyanto et al. [88] shed light on the decision-making process of life cycle assessment. In another research study, a decision-making model was developed for the remanufacturing process of recoverable inventory [89]. Mesa et al. [83] created an algorithm for decision-making to identify the best joining method in line with assembly and disassembly requirements in the product life cycle. With the use of an optimization control model, [126] concluded that this method could be used effectively for the reassembly system in remanufacturing. Bakeshloo et al. [127] implemented a Markov decision-based strategy for inventory control problems in a hybrid manufacturingremanufacturing system with stochastic demand. The model was implemented for the tire industry, and the results revealed that profitability, serviceability, and core acquisition could be improved by the proposed strategy.

Govindan et al. [7] provided insights that support decision-makers; for instance, how policy makers can benefit from how to improve the branding of remanufactured products. Paterson et al. [128] investigated several decisions such as whether or not remanufacturing is occurring and whether recycling is applicable to CFRP (carbon fiber reinforced polymer) and carbon fibers. Many other research works, such as $[7,8,12,73,74,78,83,88,89,91,126,128]$, utilized decision-making models in the remanufacturing domain.

\subsection{Uncertainty Studies in Remanufacturing}

Remanufacturing is more difficult than conventional manufacturing because of the difficulties and uncertainty involved in managing returned goods $[129,130]$. Researchers [131] studied a remanufacturing production planning model taking into consideration some possible uncertain factors in remanufacturing such as its features and characteristics. A two-stage, hybrid programming model was proposed based on the uncertainty theory to minimize the total remanufacturing cost. To show the model's efficiency, a remanufacturing simulation case was studied. Since the remanufacturing process involves many uncertainties, Um et al. [75] used a selective assembly method to reduce assembling deviation based on uncertainty analysis. The method improved production efficiency and reduced uncertainties in assembly process and repair cost, leading to customer satisfaction. Gao et al. [116] proposed an artificial bee colony (ABC) algorithm multi-objective decisionmaking approach for dealing with uncertainty in EOL products. The objective was to find the best EOL options of product recovery components and profit. In the study, a motor was used as a case study to demonstrate the methodology. The proposed approach shows that, compared with selections of EOL options that disregard uncertainty, considering uncertainty makes EOL product recovery more realistic and can give better alternatives to decision makers. 


\subsection{Other Methods and Studies}

Other topics that were covered were literature reviews conducted by $[7,11,93,132]$ on the topic of remanufacturing. Suhariyanto et al. [88] conducted a systematic review on multi-life cycle assessment for products in the remanufacturing process. The study identified gaps in the field, which will help in the understanding of multi-life cycle and life cycle assessment of these products. Ngu et al. [133] presented an in-depth study of the remanufacturing industries in Malaysia. Different aspects, challenges and issues, as well as the current status were discussed. To summarize the advancement of remanufacturing technologies, Zhang et al. [134] conducted a comprehensive literature review of investigating energy, climate, and economy in remanufacturing using the life cycle assessment (LCA) process. The LCA method's shortcomings were also addressed. Ardente et al. [135] utilized an LCA approach to assessing the environmental benefits of remanufacturing. A server was selected as a case-study product; it was reported that even though the remanufactured product consumes more energy for running, it is still environmentally beneficial.

Sutherland et al. [136] presented a comparative study in terms of energy savings between manufacturing and remanufacturing of a diesel engine. The results revealed that remanufacturing saves a significant amount of energy consumption over a life cycle of a diesel engine; moreover, hazardous emissions were also reduced.

Chen et al. [137] conducted a study on consumers and their willingness to pay for remanufactured products through a questionnaire. Govindan et al. [7] discussed marketing issues found in remanufacturing and their products. The article explored different opportunities to improve marketing approaches for remanufactured products by the use of various strategies, consumer behaviors, as well as pricing and branding. Nassehi and Colledani [125] investigated the relationship between customer behavior and manufacturer decisions using a simulation model to examine, analyze, and predict decisions of remanufacturing enterprises and their possible long-term effects on customer behavior. Feng et al. [105] studied the benefits in supply chains of remanufacturing, as they found that small recoverable product inventories have variations in return arrivals and the quality of recoverable products, which in turn affects the completion of customers' orders.

\section{Barriers and Challenges for Remanufacturing}

The concept of remanufacturing was introduced more than two decades ago; though, it is still on the ground level and is not adopted due to barriers and lack of awareness. Circularity gap report in 2019 reported that only $9 \%$ of the 92.8 billion tons of minerals, fossil fuels, metals, and biomass entering the economy are re-used each year [138]. Merely $2 \%$ of US total production and only $1.9 \%$ of EU production is remanufactured [18].

Still, there are several challenges faced by remanufacturing. One of the notions is that consumers' low willingness-to-pay for the remanufactured product is a major barrier for remanufacturing [139-142]. Sharma et al. [48] presented the roadblocks for remanufacturing India. Through surveys and literature, they reported major roadblocks, which are: (1) Quality concerns; (2) no framework, guidelines, and policies; (3) product design; (4) unorganized sector; (5) lack of marketing strategies; (6) customers' willingness to return the products; and (7) trade barriers. Wei et al. [143] discussed the barriers faced by remanufacturing industries in China. It was mentioned that the difficulties faced by remanufacturers are different for different sectors, though there are also some common barriers, such as government policies. Figure 5 shows the rank of overall barriers as presented by Wei et al. [143]. The horizontal axis shows the seriousness scale in which $1=$ not serious at all; $3=$ serious; and $5=$ extremely serious. 


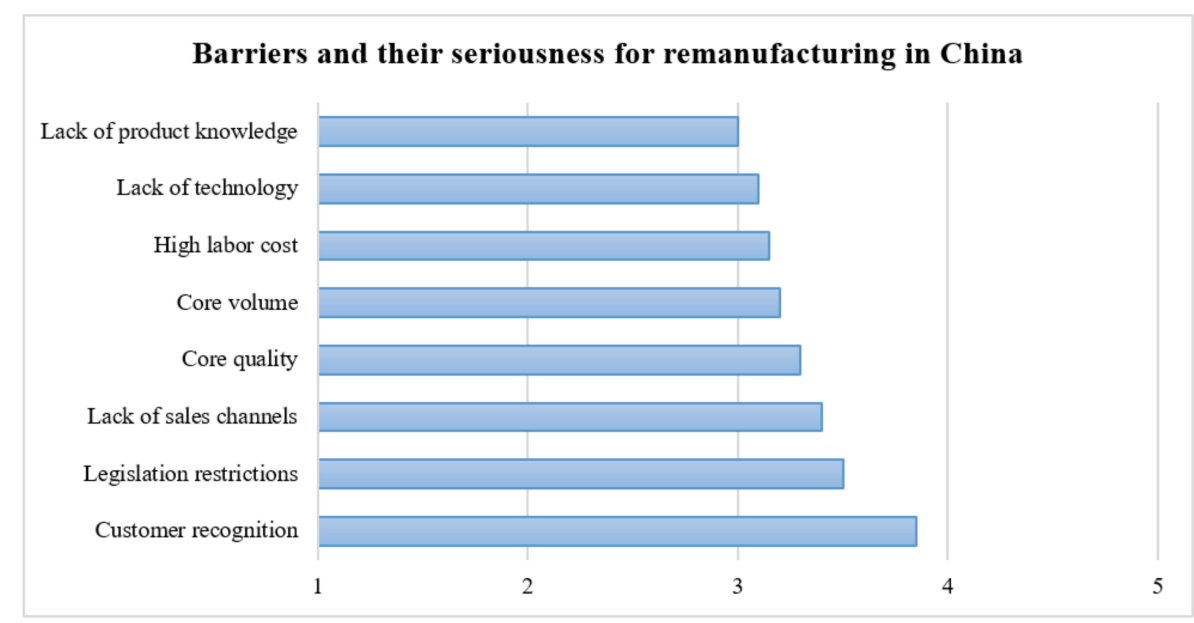

Figure 5. Overall barriers for remanufacturing in China (adapted from [143]).

Tian et al. [144] discussed barriers faced by automotive components' remanufacturing. It was reported that limitation in the supply chain is one of the barriers. Sometimes, the cost of the remanufactured product poses an issue [145]. Other barriers reported in the literature are a lack of awareness, government policies, lack of proper facilities and thinking at the design stage, and so on $[18,146]$. Zhang et al. categorized barriers into three types: before remanufacturing (design, less enthusiasm, and lack of cores); during remanufacturing (lack of technologies, lack of know-how, and scarcity of standards); and after remanufacturing (market, policies, and consciousness). Xia et al. [14] utilized the Grey-Decision-Making Trial and Evaluation Laboratory (DEMATEL) approach for investigating the internal barriers in China for automotive parts remanufacturing. Kurilova-Palisaitiene et al. [147] discussed how lean manufacturing would help with remanufacturing challenges. They identified several challenges in the remanufacturing process and categorized them into three types, as shown in Figure 6. Gunasekara et al. [20] presented a review about barriers in remanufacturing. They classified barriers into three categories, which are: academic-level barriers, policy-level barriers, and industry-level barriers. Table 2 shows the finding presented by them.

Table 2. Barriers identified by Gunasekara et al. [20].

\begin{tabular}{ll}
\hline Barriers Category & \multicolumn{1}{c}{ Description } \\
\hline \multirow{3}{*}{ Academic Level } & There are not enough remanufacturing awareness programs [148]. \\
& Remanufacturing equipment is not readily available [48]. \\
& There are not enough regional innovation research and development projects [149]. \\
& A scarcity of human capital with sufficient technical knowledge [150]. \\
\hline & There is a lack of environmental laws and regulations [148]. \\
& Policymakers' lack of support [147]. \\
Policy Level lack of financial incentive [143]. & Incentives for the growth of new industries are lacking [151]. \\
& Tax burdens are excessive [151]. \\
& There is a lack of coordination among government agencies that provide services to the industrial sector [20]. \\
& Remanufactured goods have a low demand [148]. \\
& A lack of desire to return used goods [152]. \\
& It is difficult to set up a system for returning used goods [3,153]. \\
& Balancing supply and demand is a difficult task [154]. \\
& Struggling to stay competitive with a brand new product [48,143]. \\
& Long-term investment is needed to start a remanufacturing company [148]. \\
& Investment in the remanufacturing industry is not financially viable [155]. \\
& The manufacturing industry is suffering from a lack of investment [20]. \\
& Uncertainty of quality of returned used item [147]. \\
& Complicated due to a large number of product models/variations [156] and/or fashion obsolescence [157]. \\
& The method is extremely labor-intensive (disassembly, cleaning, refurbishment, inspection, assembly, testing) [3,143,150]. \\
& Difficulty in production scheduling due to varying processes [155,156,158]. \\
& Replacement parts are difficult to come by due to price and distribution issues [143,155]. \\
Poor standards of product recovery activities such as repairing and reconditioning [20].
\end{tabular}




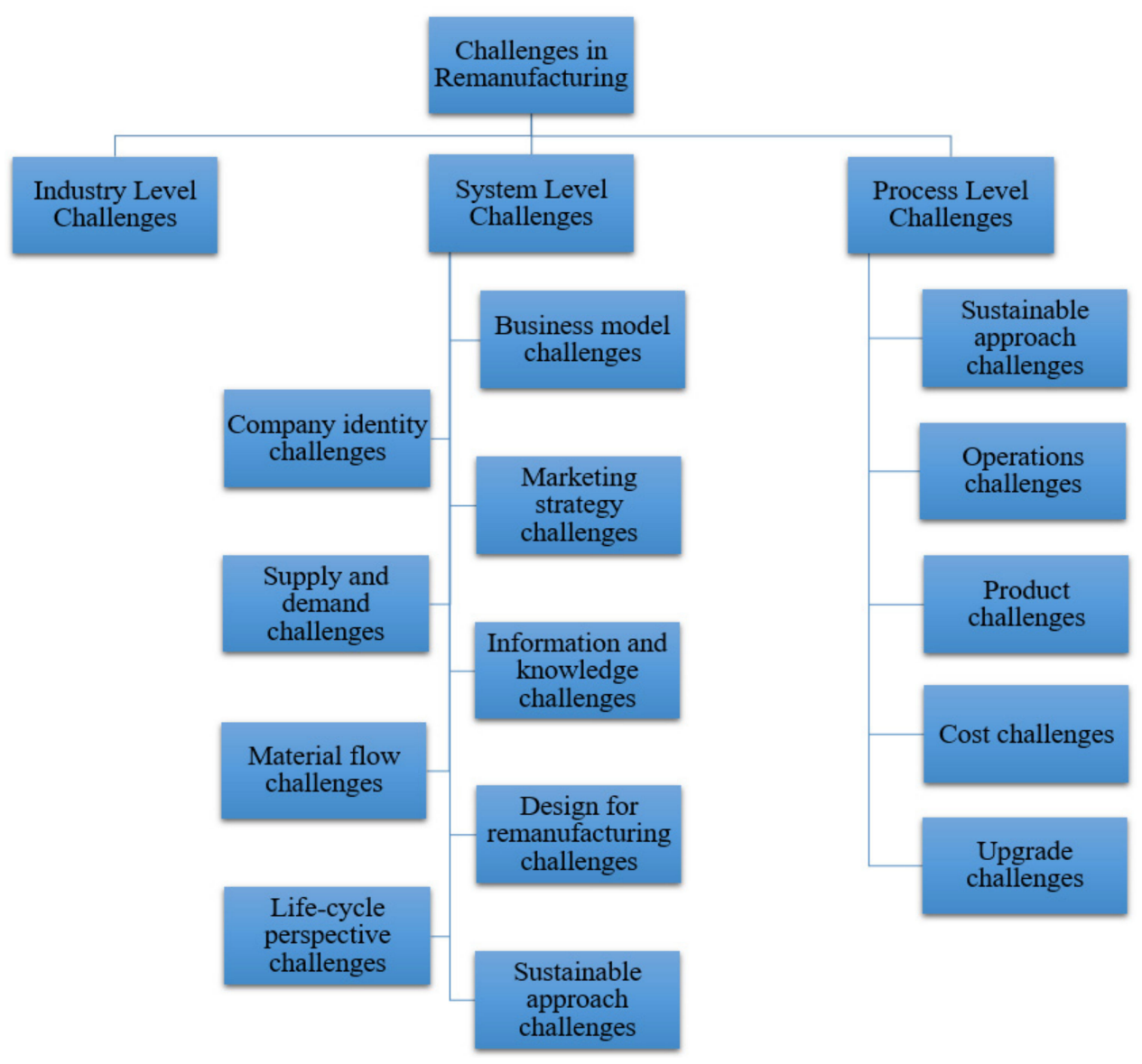

Figure 6. Challenges in remanufacturing as identified by Kurilova-Palisaitiene et al. [147].

\section{Results}

A bibliometric analysis is performed in order to have better comprehension and to know about the research trends in the remanufacturing domain, as discussed in Section 2 (Methodology). The results obtained through the bibliometric analysis are reported in this section.

\subsection{Publication and Citation Analysis}

Remanufacturing research has gained the interest of researchers in the past few years, which is demonstrated by the yearly increase in the number of publications in this field, as shown in Figure 7. Obviously, there is an increase in the number of researchers in remanufacturing, and also WOS has included more journals in the last years. According to WOS records, there are around 200 papers published each year in the field of RSC from 2016, and the number of articles in 2020 reaches 366 articles. It can be seen from literature that in the initial years of research (1980s) on remanufacturing, the focus was on the general introduction of the topic. Later, in the following decade (1990-2000), attention was paid to defining the remanufacturing process more precisely and how it is different from other allied fields, such as recycling and reconditioning. In the following 10 years (2000-2010), the focus on remanufacturing research was shifted toward solution methodologies, some guidelines development, the creation of a remanufacturing ecosystem, and so on. During the last decade (2011-2020), researchers explored various topics in the domain such as the environment benefits, design aspects, barriers for implementation, and how it supports circular economy, to name a few. Moreover, from the past few years, investigations have been started into the implementation of a fourth industrial revolution in 
the remanufacturing field, uncertainties in various processes, design for remanufacturing, advance machine learning algorithms for scheduling and planning, and so on.

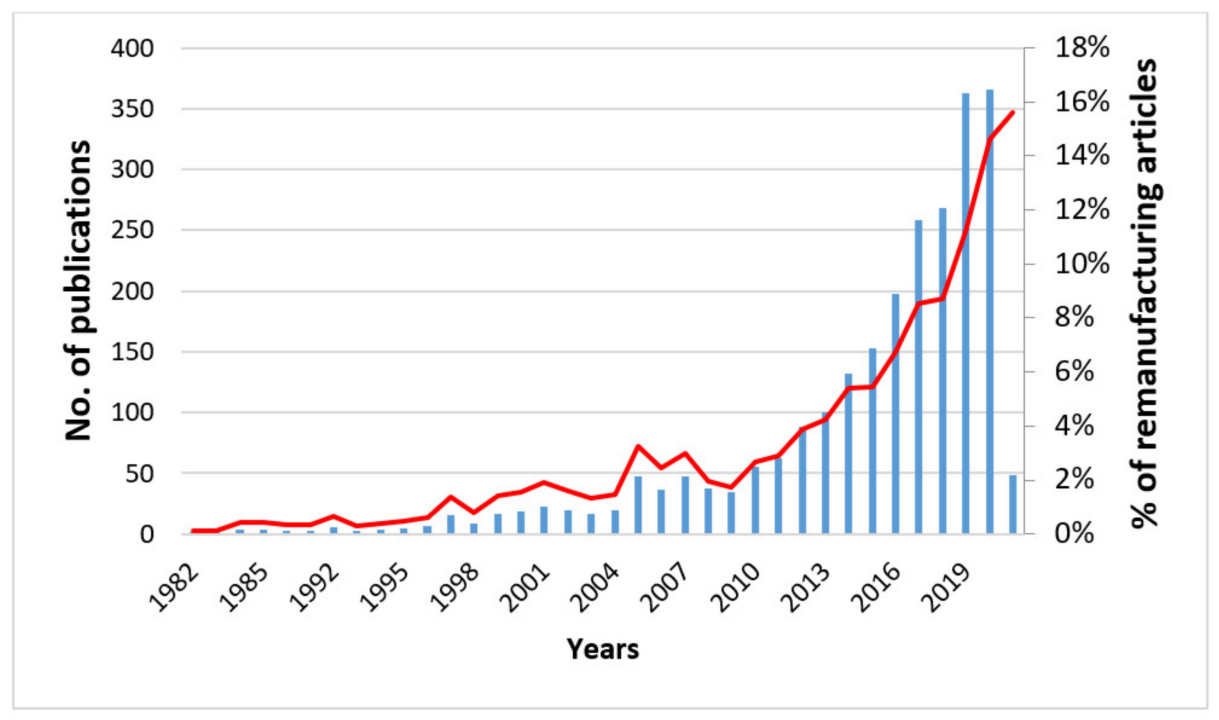

Figure 7. The number of annual publications on remanufacturing. The blue bar indicates the total number of yearly remanufacturing-related papers, and the red line indicates the ratio of yearly remanufacturing-related publications to the total publications in all fields $\times 1000$.

As research on remanufacturing is receiving more attention, the same has been reflected in the citation trends. During the last decade, remanufacturing research paper's citation rate has been high, with 136 papers having more than 100 citations. Citations provide an idea that a research area is still active and that researchers are still exploring the area. Table 3 displays the full citation record of all the papers available in WOS in the field of remanufacturing to provide a better picture of the citation. The table categorizes the articles according to the number of times they have been cited, with the percentage of every category. In addition to the 136 papers that have been cited more than 100 times, $9.6 \%$ of the total publications on remanufacturing have been cited more than 50 times. A further interesting activity is to analyze the global H-index [159], found in remanufacturing research. The H-index [160] is a measure that aims at representing the importance of a set of papers. For example, if a set of papers has an H-index of 25 , this means that 25 of the papers included in the set have received at least 25 citations each. The H-index for all of the results collected in this research study is 113 .

Table 3. Citation structure of remanufacturing papers.

\begin{tabular}{ccc}
\hline Number of Citations & Number of Papers & \% Papers \\
\hline$\geq 100$ citations & 136 & $5.5 \%$ \\
$\geq 50$ citations & 238 & $9.6 \%$ \\
$\geq 20$ citations & 455 & $18.4 \%$ \\
$<20$ citations & 1648 & $66.5 \%$ \\
total & 2477 & $100.0 \%$ \\
\hline
\end{tabular}

\subsection{Most Influential Journals in Remanufacturing Research}

Remanufacturing research projects are currently being published in various and a high number of journals, with more than 400 journals only in the WOS. To provide some information on the journals interested in remanufacturing research, Table 4 depicts the 10 top influential journals sorted by the number of publications in the field of remanufacturing. Journal of Cleaner Production (JCP) and International Journal of Production 
Research (IJPR) are the most influential journals by the sum of total publications, whereas European Journal of Operational Research (EJOR) has the most citations per item.

Table 4. Most influential journals.

\begin{tabular}{ccccc}
\hline Rank & Journal & No. of Publications & Times Cited & Citations/Article \\
\hline 1 & JCP & 313 & 10,138 & 32.39 \\
2 & IJPR & 172 & 4636 & 26.95 \\
3 & IJPE & 155 & 6766 & 43.65 \\
4 & Sustainability & 93 & 684 & 7.35 \\
5 & IJAMT & 90 & 1595 & 17.72 \\
6 & CIE & 81 & 2637 & 32.56 \\
7 & EJOR & 78 & 4186 & 53.67 \\
8 & POM & 47 & 3822 & 81.32 \\
9 & RCR & 45 & 1938 & 43.07 \\
10 & JMS & 28 & 964 & 34.43 \\
\hline
\end{tabular}

JCP-Journal of Cleaner Production; IJPR—International Journal of Production Research; IJPE-International Journal of Production Economics; IJAMT-International Journal of Advanced Manufacturing Technology; CIE-Computers and Industrial Engineering; EJOR-European Journal of Operational Research; POM-Production and Operations Management; RCR—Resources, Conservation \& Recycling; JMS—Journal of Manufacturing Systems.

To generate more useful information, a trend analysis was conducted with respect to the most influential journals. To this end, the whole study period was divided into several intervals, and the most influential journals within each interval were analyzed to assess the trends, as shown in Figure 8. The results show that JCP is the most interested in remanufacturing research in recent years.

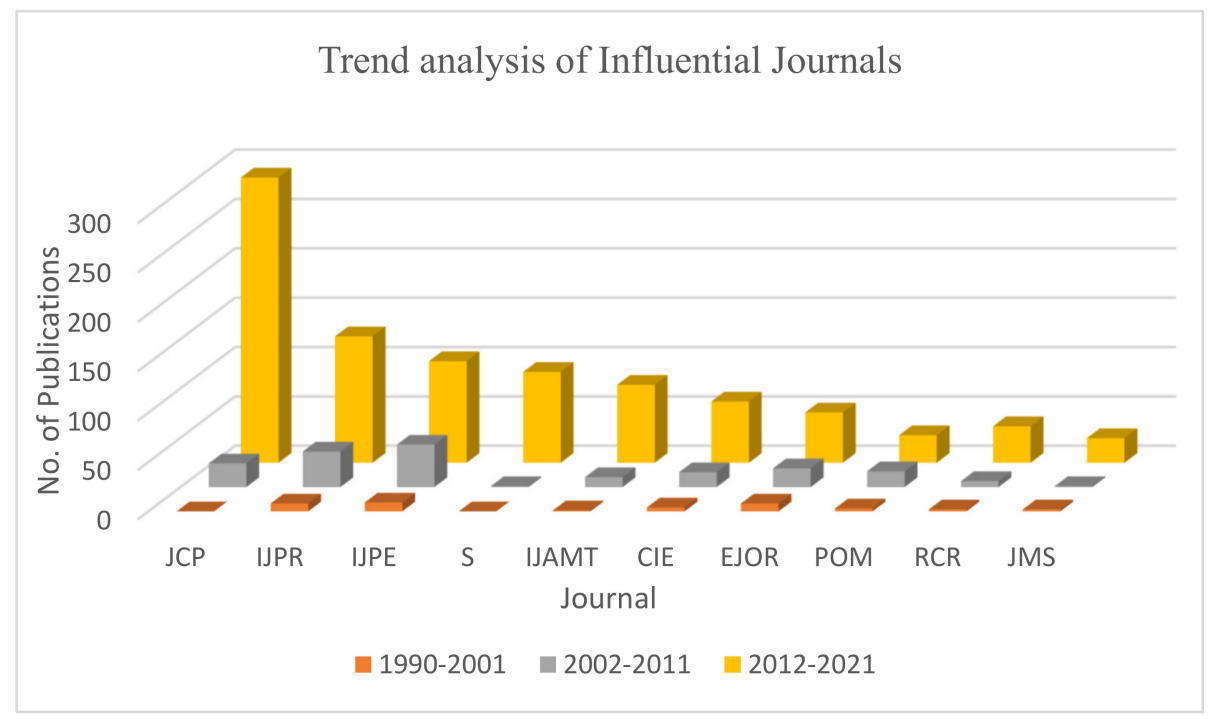

Figure 8. Trend analysis of the most influential journals on remanufacturing.

To focus on the more important papers on remanufacturing, all of the search projects were sorted according to the highest cited papers. Therefore, it is possible to collect articles that have received more citations in the field of remanufacturing. The more citations received by an article, the more important and popular it is in that field because the articles with new and useful ideas are always cited more. Table 5 shows the 10 most cited papers available on WOS in the period under consideration for remanufacturing research. 
Table 5. Most influential articles on remanufacturing, based on WOS database.

\begin{tabular}{ccccccc}
\hline Rank & Journal & Article & TC & Author/s & Year & C/Y \\
\hline 1 & MS & {$[161]$} & 1045 & Savaskan, RC; Bhattacharya, S; Van Wassenhove, LN & 2004 & 65.31 \\
2 & CIE & {$[162]$} & 605 & Gungor, A; Gupta, SM & 1999 & 28.81 \\
3 & JOM & {$[163]$} & 584 & Guide, VDR & 2000 & 29.20 \\
4 & JEM & {$[165]$} & 545 & Ilgin, Mehmet Ali; Gupta, Surendra M. & 2010 & 54.50 \\
5 & JCP & {$[164]$} & 531 & Lieder, Michael; Rashid, Amir & 2016 \\
6 & MS & {$[166]$} & 436 & Savaskan, RC; Van Wassenhove, LN & 2006 \\
7 & MS & {$[167]$} & 434 & Atasu, Atalay; Sarvary, Miklos; Van Wassenhove & 2008 \\
8 & MS & {$[168]$} & 419 & Ferrer, G; Swaminathan, JM & 31.14 \\
9 & POM & {$[169]$} & 395 & Ferguson, Mark E.; Toktay, L. Beril & 2006 \\
10 & MS & {$[170]$} & 390 & Debo, LG; Toktay, LB; Van Wassenhove, LN & 2006 & 29.93 \\
\hline
\end{tabular}

MS—Management SCIENCE; JOM—Journal of Operations Management; JEM—Journal of Environmental Management; TC—Times Cited; C/Y-Citations per Year.

It is clear from Table 5 that the paper published by Savaskan et al., in 2004 [161], is the most cited and popular one. Next are the paper published by Gungor A. and Gupta S.M., in 1999 [162], and the paper by Guide, in 2000 [163], with more than 500 citations for each. There are several other influential authors; for example, the recent paper in 2016 by Lieder et al. [164] has the most citations per year in the list.

\subsection{An Overview of the Most Productive and Influential Authors in Remanufacturing Research}

Many authors are playing a key role in remanufacturing research studies. It is an important issue to determine which authors have the highest presence and influence. Table 6 presents the 10 most influential authors with the greatest number of publications in the field of remanufacturing. Note that the number of articles published is only an indicative measure; this is because many factors must be considered, such as co-authorship, paper size, and journal quality. Therefore, in order to present a full picture of all of these most active and influential studies, many other indicators were added in Table 6, such as the total citations received by each author, H-index, and citations per item. Table 6 shows that Guide V.D.R. is the most influential author in the field of remanufacturing, with more than 3600 citations, followed by Gupta S.M., with 2387 citations, regardless of the small number of articles he published; next is Adenso-Govindan K, with 1149 citations. Regarding the number of publications, Guide is also ranked high with 34 papers published in the field of remanufacturing; next in line are Xu B.S (34 papers), Gupta S.M. (32 papers), and so on.

Table 6. Most productive and influential authors in remanufacturing research.

\begin{tabular}{cccccc}
\hline Rank & Name & TP & TC & H & Citations per Item \\
\hline 1 & Guide VDR & 34 & 3603 & 26 & 105.97 \\
2 & Xu BS & 34 & 270 & 9 & 7.94 \\
3 & Gupta SM & 32 & 2387 & 18 & 74.59 \\
4 & Wang Y & 31 & 440 & 11 & 14.19 \\
5 & Zhang H & 31 & 422 & 12 & 13.61 \\
6 & Zhang HC & 28 & 374 & 12 & 13.36 \\
7 & Jiang ZG & 26 & 481 & 12 & 18.50 \\
8 & Li YJ & 22 & 716 & 12 & 32.55 \\
9 & Li BY & 20 & 206 & 9 & 10.30 \\
10 & Govindan K & 19 & 1149 & 16 & 60.47 \\
\hline
\end{tabular}

$\mathrm{TP}$-total publications; $\mathrm{H}-\mathrm{H}$-index.

\subsection{Most Productive and Influential Institutions in Remanufacturing Research}

Remanufacturing research projects are conducted in more than 500 institutions. Many of these institutions are popular, and the 10 most influential institutions in remanufacturing are presented in Table 7, sorted according to the total number of publications (TP). The results of Table 7 reveal that the Indian Institute of Technology System has the most TP 
in the field of remanufacturing. However, Northeastern University is the most cited institution and has the most rate of citations per item. In this list, most of the institutions are from China, and in general, $80 \%$ of the institutions are Asian organizations. It is worth noting that only two USA institutes have been found in this list, and no European institute has been listed.

Table 7. Most productive and influential institutions in remanufacturing research.

\begin{tabular}{|c|c|c|c|c|c|c|}
\hline Rank & Name & Country & H-Index & TP & TC & $\mathbf{C} / \mathbf{P}$ \\
\hline 1 & Indian Institute of Technology Systems & India & 18 & 54 & 984 & 18.22 \\
\hline 2 & Chongqing University & China & 22 & 53 & 1101 & 20.77 \\
\hline 3 & Huazhong University of Science and Technology & China & 22 & 53 & 1425 & 26.89 \\
\hline 4 & Dalian University of Technology & China & 16 & 49 & 1074 & 21.92 \\
\hline 5 & Hefei University of Technology & China & 10 & 44 & 266 & 6.05 \\
\hline 6 & Nanjing University of Aeronautics and Astronautics & China & 11 & 39 & 349 & 8.95 \\
\hline 7 & Northeastern University & USA & 22 & 39 & 2605 & 66.79 \\
\hline 8 & Shanghai Jiao Tong University & China & 15 & 39 & 656 & 16.82 \\
\hline 9 & Pennsylvania Commonwealth System of Higher Education & USA & 20 & 38 & 1819 & 47.87 \\
\hline 10 & Wuhan University of Science and Technology & China & 12 & 37 & 498 & 13.46 \\
\hline
\end{tabular}

\section{Discussion}

Remanufacturing is gaining admiration because it is a step toward sustainable manufacturing. It is closely related to the circular economy, and one can say that it is one of its pillars. Remanufacturing possesses several benefits in terms of saving in cost, time, and energy. However, still many aspects need to be explored in order to make it a success.

Researchers around the world have started investigating various facets of remanufacturing. Based on this comprehensive literature review, it can be said that most of the focus was made on common phases of remanufacturing, such as disassembly cleansing, condition assessment, and solution techniques.

Industry 4.0 is gaining a lot of momentum in the manufacturing field; hence, its implementation in the remanufacturing domain should also be explored. Some research projects have been started in this domain as well [171-174]. Industry 4.0 tools, such as the Internet of Things (IoT) and big data analysis, will be quite useful in reverse logistics [175], predictive maintenance [176], and assessment of EOL products [172]. Disassembly and assembly are integral parts of the remanufacturing process. Tools such as augmented reality (AR)/virtual reality (VR) are quite useful in assembly/disassembly planning [177].

Secondly, uncertainties in various factors such as demand, transportation, and production still require research from the perspective of remanufacturing [129]. Many researchers have proposed mathematical models and techniques for optimization in manufacturing [178,179]; though, in remanufacturing, still a lot of effort is required, including the dynamic nature of remanufacturing process and also the multi-criteria involved $[180,181]$.

In terms of national and international policies, still much synergy is required; because it is vital to identify the barriers that are hindering the implementation of remanufacturing and then finding ways to eradicate those barriers [20,182].

Design for remanufacturing is another important area that needs to be explored because it is better to think from the start how the product will be designed so that it will support the remanufacturing process later $[63,183]$. All of these research directions required joint efforts from researchers around the world to make the manufacturing process greener and more sustainable.

\section{Conclusions}

In this paper, the literature on remanufacturing was comprehensively reviewed. A detailed investigation of various aspects of remanufacturing was carried out qualitatively as well as quantitatively to address the four research questions mentioned in Section 1 . The goal of RQ1 is to differentiate remanufacturing with other related terminologies. Several 
definitions of remanufacturing provided by researchers and organizations were presented, and we discussed how it is different from other close concepts

To address RQ2 (major phases and solution methodologies employed for remanufacturing), several aspects of remanufacturing and the solution methodologies applied in this domain were presented from the literature. It can be seen that mathematical modellingbased optimization techniques as well as simulation techniques are quite well explored by researchers, and the dynamic nature of remanufacturing activities' uncertainty models are also included at some instances.

Even with so many benefits and gains, remanufacturing implementation on the ground level is still not discernable; thus, factors that are creating obstacles in its execution are presented in order to answer RQ3 (barriers and challenges in remanufacturing adoption). From the literature, it can be concluded that government support and customers' willingness both are required to make remanufacturing successful.

Finally, to address RQ4 (research trends and future research directions), apart from a qualitative literature review, bibliometric analysis was performed, and trends and research distributions were analyzed and discussed. Both qualitative and quantitative analysis research trends and future research directions were identified.

Based on the literature review, it can be seen that barriers and challenges are the least investigated in the literature. It can be concluded that researchers should pay more attention to barriers and challenges while also providing solutions to these issues. Though design for remanufacturing is an obvious enabler for remanufacturing, yet this review indicates that research is lacking on this perspective; the design phase is found to be the least investigated among other phases of remanufacturing. Moreover, the testing phase also requires attention from researchers. Another conclusion that emerges from bibliometric research is that developing countries such as China and India are studying it more than developed countries.

Based on the qualitative and quantitative literature analysis, some of the future research directions are listed as follows:

- Barriers in Adoption: Several barriers and challenges are identified by researchers. Some challenges are global while the others differ from region to region, such as local government policies, customer behavior, and so on. Some challenges need more investigation to include uncertainty of core supply, discontinuity of replacement part supply, lack of product knowledge among consumers and retailers, hesitation of retailers to sell remanufactured products, and government policies, to name a few.

- Uncertainties: The dynamic nature of various remanufacturing activities creates several uncertainties that need to be explored, such as changes in demand, resource allocation, transport issues, and so on.

- Solution Methods: As complexity increases, the solution methods to model the process are also required to be updated. Updated models with the help of the latest algorithms are required in different solution methodology techniques such as multi-criteria decision making, mathematical modeling, simulation methods, and meta-heuristics.

- Design for Remanufacturing: If, from the start, the designer develops a product while keeping in mind its remanufacturing process, then several problems will be resolved. Design for remanufacturing includes both design for disassembly as well as design for assembly. More investigations are required in the initial level of design, developing know-how, and creating design guidelines.

- Industry 4.0 for Remanufacturing: Industry 4.0 in usual manufacturing has been gaining much popularity since the last decade. However, there is a scarcity of research for implementing Industry 4.0 tools such as Internet of Things (IoT), artificial intelligence tools, and big data analytics in remanufacturing. 
Author Contributions: Conceptualization, B.S., A.Z. and M.A. (Mohammed Alkahtani); Methodology, A.Z., B.S., M.A. (Mohammed Alkahtani), A.B. and U.S.; Software, M.A. (Moath Alatefi) and A.A.; Formal analysis, A.Z., A.B., M.A. (Moath Alatefi) and U.S.; Investigation, B.S., A.Z. and M.A. (Mohammed Alkahtani); Resources, B.S. and M.A. (Mohammed Alkahtani); Data curation, M.A. (Moath Alatefi), A.B., A.A. and U.S.; Writing-original draft preparation, B.S., A.Z., A.B. and U.S.; Writing-review and editing, B.S., M.A. (Mohammed Alkahtani) and A.Z.; Supervision, B.S., A.Z. and M.A. (Mohammed Alkahtani); Project administration, B.S., A.Z. and M.A. (Mohammed Alkahtani); Funding acquisition, B.S., A.Z. and M.A. (Mohammed Alkahtani). All authors have read and agreed to the published version of the manuscript.

Funding: This work was supported by the National Plan for Science, Technology, and Innovation (MAARIFAH), King Abdulaziz City for Science and Technology, Saudi Arabia, under Award 15-ENE4953-02.

Data Availability Statement: Not applicable.

Acknowledgments: Authors would like to thank the National Plan for Science, Technology, and Innovation (MAARIFAH), King Abdulaziz City for Science and Technology, Saudi Arabia, for funding this work under Award 15-ENE4953-02.

Conflicts of Interest: The authors declare no conflict of interest.

\section{References}

1. Matsumoto, M.; Ijomah, W. Remanufacturing. In Handbook of Sustainable Engineering; Kauffman, J., Lee, K.-M., Eds.; Springer: Berlin/Heidelberg, Germany, 2013; pp. 389-408. [CrossRef]

2. Ijomah, W.L. The application of remanufacturing in sustainable manufacture. Proc. Inst. Civ. Eng. 2010, 163, 157-163. [CrossRef]

3. Lund, R.T.; Hauser, W.M. Remanufacturing-An American perspective. In Proceedings of the 5th International Conference on Responsive Manufacturing-Green Manufacturing (ICRM 2010), Ningbo, China, 11-13 January 2010; pp. 1-6.

4. Nasr, N.; Hilton, B.; German, R. A framework for sustainable production and a strategic approach to a key enabler: Remanufacturing. In Advances in Sustainable Manufacturing; Springer: Berlin, Heidelberg, 2011; pp. 191-196.

5. Junior, M.L.; Filho, M.G. Production planning and control for remanufacturing: Literature review and analysis. Prod. Plan. Control 2012, 23, 419-435. [CrossRef]

6. Fatimah, Y.A.; Biswas, W.; Mazhar, I.; Islam, M.N. Sustainable manufacturing for Indonesian small- and medium-sized enterprises (SMEs): The case of remanufactured alternators. J. Remanuf. 2013, 3, 6. [CrossRef]

7. Govindan, K.; Jimenez-Parra, B.; Rubio, S.; Vicente-Molina, M.A. Marketing issues for remanufactured products. J. Clean Prod. 2019, 227, 890-899. [CrossRef]

8. Den Hollander, M.C.; Bakker, C.A.; Hultink, E.J. Product Design in a Circular Economy Development of a Typology of Key Concepts and Terms. J. Ind. Ecol. 2017, 21, 517-525. [CrossRef]

9. Giutini, R.; Gaudette, K.J. Remanufacturing: The next great opportunity for boosting US productivity. Bus. Horiz. 2003, 46, 41-48. [CrossRef]

10. Li, K.; Liu, J.; Fu, H.; Liu, B. Acquisition and pricing strategies in hybrid manufacturing-remanufacturing systems. J. Manuf. Syst. 2020, 57, 217-230. [CrossRef]

11. Zhang, X.F.; Zhang, S.Y.; Zhang, L.C.; Xue, J.F.; Sa, R.; Liu, H. Identification of product's design characteristics for remanufacturing using failure modes feedback and quality function deployment. J. Clean Prod. 2019, 239, 14. [CrossRef]

12. Fang, H.; Ong, S.; Nee, A.J. Product remanufacturability assessment and implementation based on design features. Procedia CIRP 2015, 26, 571-576. [CrossRef]

13. Subramoniam, R.; Huisingh, D.; Chinnam, R.B. Aftermarket remanufacturing strategic planning decision-making framework: Theory \& practice. J. Clean. Prod. 2010, 18, 1575-1586.

14. Xia, X.; Govindan, K.; Zhu, Q. Analyzing internal barriers for automotive parts remanufacturers in China using grey-DEMATEL approach. J. Clean. Prod. 2015, 87, 811-825. [CrossRef]

15. Jiang, Z.; Zhou, T.; Zhang, H.; Wang, Y.; Cao, H.; Tian, G. Reliability and cost optimization for remanufacturing process planning. J. Clean. Prod. 2016, 135, 1602-1610. [CrossRef]

16. Smith, V.M.; Keoleian, G.A. The Value of Remanufactured Engines: Life-Cycle Environmental and Economic Perspectives. J. Ind. Ecol. 2004, 8, 193-221. [CrossRef]

17. McCracken, G.A.; Christiansen, R.; Turpin, M. The Environmental Benefits of Remanufacturing: Beyond SF6 Emission Remediation; EPA—United States Environmental Protection Agency: NC, USA, 2016. Available online: https://www.epa.gov/sites/ production/files/2016-02/documents/conf00_mccracken_paper.pdf (accessed on 1 March 2021).

18. Nasr, N.Z.; Russell, J.D.; Bringezu, S.; Hellweg, S.; Hilton, B.; Kreiss, C.; von Gries, N. Re-defining Value-The Manufacturing Revolution. Remanufacturing, Refurbishment, Repair and Direct Reuse in the Circular Economy; International Resource Panel (IRP), United Nations Environment Programme: Paris, France, 2018; p. 272. Available online: https://www.resourcepanel.org/reports/ re-defining-value-manufacturing-revolution (accessed on 25 February 2021). 
19. Sitcharangsie, S.; Ijomah, W.; Wong, T.C. Decision makings in key remanufacturing activities to optimise remanufacturing outcomes: A review. J. Clean. Prod. 2019, 232, 1465-1481. [CrossRef]

20. Gunasekara, H.; Gamage, J.; Punchihewa, H. Remanufacture for sustainability: Barriers and solutions to promote automotive remanufacturing. Procedia Manuf. 2020, 43, 606-613. [CrossRef]

21. Fofou, R.F.; Jiang, Z.; Wang, Y. A Review on the Lifecycle Strategies Enhancing Remanufacturing. Appl. Sci. 2021, $11,5937$. [CrossRef]

22. Liu, C.; Zhu, Q.; Wei, F.; Rao, W.; Liu, J.; Hu, J.; Cai, W. A review on remanufacturing assembly management and technology. Int. J. Adv. Manuf. Technol. 2019, 105, 4797-4808. [CrossRef]

23. Wahab, D.A.; Blanco-Davis, E.; Ariffin, A.K.; Wang, J. A review on the applicability of remanufacturing in extending the life cycle of marine or offshore components and structures. Ocean Eng. 2018, 169, 125-133. [CrossRef]

24. Rizova, M.I.; Wong, T.C.; Ijomah, W. A systematic review of decision-making in remanufacturing. Comput. Ind. Eng. 2020, 147, 106681. [CrossRef]

25. Morgan, S.D.; Gagnon, R.J. A systematic literature review of remanufacturing scheduling. Int. J. Prod. Res. 2013, 51, 4853-4879. [CrossRef]

26. Podsakoff, P.M.; MacKenzie, S.B.; Podsakoff, N.P.; Bachrach, D.G. Scholarly influence in the field of management: A bibliometric analysis of the determinants of university and author impact in the management literature in the past quarter century. J. Manag. 2008, 34, 641-720. [CrossRef]

27. Baltagi, B.H. Worldwide econometrics rankings: 1989-2005. Econom. Theory 2007, 23, 952-1012. [CrossRef]

28. Wagstaff, A.; Culyer, A.J. Four decades of health economics through a bibliometric lens. J. Health Econ. 2012, 31, 406-439. [CrossRef]

29. Seggie, S.H.; Griffith, D.A. What does it take to get promoted in marketing academia? Understanding exceptional publication productivity in the leading marketing journals. J. Mark. 2009, 73, 122-132. [CrossRef]

30. Genest, C.; Guay, M. Worldwide research output in probability and statistics: An update. Can. J. Stat. 2002, 30, 329-342. [CrossRef]

31. Hoepner, A.G.; Kant, B.; Scholtens, B.; Yu, P.-S. Environmental and ecological economics in the 21st century: An age adjusted citation analysis of the influential articles, journals, authors and institutions. Ecol. Econ. 2012, 77, 193-206. [CrossRef]

32. Deng, G.-F.; Lin, W.-T. Citation analysis and bibliometric approach for ant colony optimization from 1996 to 2010 . Expert Syst. Appl. 2012, 39, 6229-6237. [CrossRef]

33. Leone, R.P.; Robinson, L.M.; Bragge, J.; Somervuori, O. A citation and profiling analysis of pricing research from 1980 to $2010 . J$. Bus. Res. 2012, 65, 1010-1024. [CrossRef]

34. Landström, H.; Harirchi, G.; Åström, F. Entrepreneurship: Exploring the knowledge base. Res. Policy 2012, 41, 1154-1181. [CrossRef]

35. Holsapple, C.W.; Lee-Post, A. Behavior-based analysis of knowledge dissemination channels in operations management. Omega 2010, 38, 167-178. [CrossRef]

36. Hsieh, P.-N.; Chang, P.-L. An assessment of world-wide research productivity in production and operations management. Int. J. Prod. Econ. 2009, 120, 540-551. [CrossRef]

37. Pilkington, A.; Meredith, J. The evolution of the intellectual structure of operations management-1980-2006: A citation/cocitation analysis. J. Oper. Manag. 2009, 27, 185-202. [CrossRef]

38. Liu, J.S.; Lu, L.Y.; Lu, W.-M.; Lin, B.J. Data envelopment analysis 1978-2010: A citation-based literature survey. Omega 2013, 41, 3-15. [CrossRef]

39. Yin, M.-S. Fifteen years of grey system theory research: A historical review and bibliometric analysis. Expert Syst. Appl. 2013, 40, 2767-2775. [CrossRef]

40. Fagerberg, J.; Fosaas, M.; Sapprasert, K. Innovation: Exploring the knowledge base. Res. Policy 2012, 41, 1132-1153. [CrossRef]

41. Merigó, J.M.; Gil-Lafuente, A.M.; Yager, R.R. An overview of fuzzy research with bibliometric indicators. Appl. Soft Comput. 2015, 27, 420-433. [CrossRef]

42. Martín-Martín, A.; Orduna-Malea, E.; Thelwall, M.; Delgado-López-Cózar, E. Google Scholar, Web of Science, and Scopus: Which is best for me? In LSE Blog; London School of Economics and Political Science: London, UK, 2019; Available online: https:/ /blogs. lse.ac.uk/impactofsocialsciences/2019/12/03/google-scholar-web-of-science-and-scopus-which-is-best-for-me/ (accessed on 20 February 2021).

43. Li, K.; Rollins, J.; Yan, E. Web of Science use in published research and review papers 1997-2017: A selective, dynamic, crossdomain, content-based analysis. Scientometrics 2018, 115, 1-20. [CrossRef]

44. Zhu, J.; Liu, W. A tale of two databases: The use of Web of Science and Scopus in academic papers. Scientometrics 2020, 123, 321-335. [CrossRef]

45. Haynsworth, H.; Lyons, R. Remanufacturing by design, the missing link. Prod. Inventory Manag. 1987, $28,24-29$.

46. Amezquita, T.; Hammond, R.; Salazar, M.; Bras, B. Characterizing the remanufacturability of engineering systems. In Proceedings of the 1995 ASME Advances in Design Automation Conference, Boston, MA, USA, 17-20 September 1995; pp. $271-278$.

47. Ijomah, W. A Model-Based Definition of the Generic Remanufacturing Business Process; University of Plymouth: Plymouth, UK, 2002.

48. Sharma, V.; Garg, S.K.; Sharma, P.B. Identification of major drivers and roadblocks for remanufacturing in India. J. Clean. Prod. 2016, 112, 1882-1892. [CrossRef] 
49. Nasr, N.; Thurston, M. Remanufacturing: A key enabler to sustainable product systems. In Proceedings of the LCE2006-13th CIRP International Conference on Life Cycle Engineering, Leuven, Belgium , 31 May-2 June 2006; pp. 15-18.

50. World Trade Organization. Market Access for Non-Agricultural Goods: Answers to Questions from China on Remanufacturing. Negotiating Group on Market Access. 2009. Available online: https://docs.wto.org/dol2fe/Pages/FE_Search/DDFDocuments/ 100418/Q/TN/MA/S16R11.pdf (accessed on 3 March 2021).

51. USITC. PDF Icon Remanufactured Goods: An Overview of the U.S. and Global Industries, Markets, and Trade; United States International Trade Commission: Washington, DC, USA, 2012; p. 284. Available online: https://www.usitc.gov/publications/332/pub4356.pdf (accessed on 3 March 2021).

52. Motor and Equipment Remanufacturing Association. Remanufacturing Associations Agree on International Industry Definition. Euractiv: 2016. Available online: http:/ / pr.euractiv.com/pr/remanufacturing-associations-agree-international-industrydefinition-146015 (accessed on 4 March 2021).

53. Golisano Institute for Sustainability. Whar is Remanufacturing? Available online: https://www.rit.edu/sustainabilityinstitute/ blog/what-remanufacturing (accessed on 26 September 2021).

54. Zhang, D.; Zhang, X.; Shi, B.; Cao, J.; Zhou, G. Collection and Remanufacturing of Waste Products under Patent Protection and Government Regulation. Sustainability 2018, 10, 1402. [CrossRef]

55. Priyono, A.; Ijomah, W.; Bititci, U. Disassembly for remanufacturing: A systematic literature review, new model development and future research needs. J. Ind. Eng. Manag. 2016, 9, 34. [CrossRef]

56. Zhang, X.; Tang, Y.; Zhang, H.; Jiang, Z.; Cai, W. Remanufacturability evaluation of end-of-life products considering technology, economy and environment: A review. Sci. Total Environ. 2021, 764, 142922. [CrossRef]

57. Liu, W.; Zhang, B.; Li, M.Z.; Li, Y.; Zhang, H.-C. Study on remanufacturing cleaning technology in mechanical equipment remanufacturing process. In Proceedings of the Re-engineering Manufacturing for Sustainability, Singapore, 17-19 April 2013; pp. 643-648.

58. Zhang, Y. Review of Non-destructive Testing for Remanufacturing of High-end Equipment. J. Mech. Eng. 2013, 49, 80. [CrossRef]

59. Zhang, H.-C.; Liu, S.; Lu, H.; Zhang, Y.; Hu, Y. Remanufacturing and remaining useful life assessment. In Handbook of Manufacturing Engineering and Technology; Nee, A.Y.C., Ed.; Springer: Berlin/Heidelberg, Germany, 2015; pp. $3137-3193$. [CrossRef]

60. Sundin, E. Product and Process Design for Successful Remanufacturing; Linköpings Universitet: Linköping, Sweden, 2004.

61. Prendeville, S.; Bocken, N. Design for remanufacturing and circular business models. In Sustainability Through Innovation in Product Life Cycle Design; Matsumoto, M., Masui, K., Fukushige, S., Kondoh, S., Eds.; Springer: Berlin/Heidelberg, Germany, 2017; pp. 269-283. [CrossRef]

62. Lindkvist Haziri, L.; Sundin, E. Supporting design for remanufacturing-A framework for implementing information feedback from remanufacturing to product design. J. Remanuf. 2020, 10, 57-76. [CrossRef]

63. Fegade, V.; Shrivatsava, R.L.; Kale, A.V. Design for Remanufacturing: Methods and their Approaches. Mater. Today Proc. 2015, 2, 1849-1858. [CrossRef]

64. Ijomah, W.L.; McMahon, C.A.; Hammond, G.P.; Newman, S.T. Development of design for remanufacturing guidelines to support sustainable manufacturing. Robot. Comput.-Integr. Manuf. 2007, 23, 712-719. [CrossRef]

65. Charter, M.; Gray, C. Remanufacturing and product design. Int. J. Prod. Dev. 2008, 6, 375-392. [CrossRef]

66. Hatcher, G.D.; Ijomah, W.L.; Windmill, J.F.C. Integrating design for remanufacture into the design process: The operational factors. J. Clean. Prod. 2013, 39, 200-208. [CrossRef]

67. Lindkvist Haziri, L.; Sundin, E.; Sakao, T. Feedback from Remanufacturing: Its Unexploited Potential to Improve Future Product Design. Sustainability 2019, 11, 4037. [CrossRef]

68. Sundin, E.; Bras, B. Making functional sales environmentally and economically beneficial through product remanufacturing. $J$. Clean. Prod. 2005, 13, 913-925. [CrossRef]

69. Allwood, J.M.; Ashby, M.F.; Gutowski, T.G.; Worrell, E. Material efficiency: Providing material services with less material production. Philos. Trans. R. Soc. A 2013, 371, 20120496. [CrossRef]

70. Cheng, Q.; Guo, Y.L.; Liu, Z.F.; Zhang, G.J.; Gu, P.H. A new modularization method of heavy-duty machine tool for green remanufacturing. Proc. Inst. Mech. Eng. Part C J. Eng. Mech. Eng. Sci. 2018, 232, 4237-4254. [CrossRef]

71. Sitek, J.; Koscielski, M.; Arazna, A.; Janeczek, K.; Steplewski, W. Investigations of BGA Components' Balls Remanufacturing Techniques for Circular Economy Applications; IEEE: New York, NY, USA, 2018.

72. Gong, Q.S.; Zhang, H.; Jiang, Z.G.; Wang, H.; Wang, Y.; Hu, X.L. Nonempirical hybrid multi-attribute decision-making method for design for remanufacturing. Adv. Manuf. 2019, 7, 423-437. [CrossRef]

73. Huang, W.H.; Jiang, Z.G.; Wang, T.; Wang, Y.; Hu, X.L. Remanufacturing Scheme Design for Used Parts Based on Incomplete Information Reconstruction. Chin. J. Mech. Eng. 2020, 33, 14. [CrossRef]

74. Ramachandran, M.; Agarwal, N. Identification of most affected parameter for design for remanufacturing of scrap piston by Taguchi desirability function analysis. In Man-Machine Interactions 5, Icmmi 2017; Gruca, A., Czachorski, T., Harezlak, K., Kozielski, S., Piotrowska, A., Eds.; Springer: Berlin/Heidelberg, Germany, 2018; Volume 659, pp. 320-329.

75. Um, J.; Suh, S.H. Design Method for Developing a Product Recovery Management System based on Life Cycle Information. Int. J. Precis. Eng. Manuf.-Green Technol. 2015, 2, 173-187. [CrossRef] 
76. Zhang, Y.; Li, J.F.; Xin, T.Y.; Cheng, C.Y. Research on carbon cleaning used by alkaline binary nitrate molten salt based on remanufacture cleaning. In Proceedings of the 2015 Seventh International Conference on Measuring Technology and Mechatronics Automation, Nanchang, China, 13-14 June 2015; pp. 849-851. [CrossRef]

77. Ke, C.; Jiang, Z.; Zhang, H.; Wang, Y.; Zhu, S. An intelligent design for remanufacturing method based on vector space model and case-based reasoning. J. Clean. Prod. 2020, 277, 123269. [CrossRef]

78. Joshi, A.D.; Gupta, S.M. Analysis of product designs for product recovery using linear physical programming. In Proceedings of the 2018 IEEE International Conference on Industrial Engineering and Engineering Management, Bangkok, Thailand, 16-19 December 2018; pp. 1508-1512.

79. Smith, S.; Hung, P.Y. A novel selective parallel disassembly planning method for green design. J. Eng. Des. 2015, 26, 283-301. [CrossRef]

80. Dong, Q.; Xu, G.N.; Ren, H.L.; Wang, A.H. Fatigue remaining life estimation for remanufacturing truck crane Jib structure based on random load spectrum. Fatigue Fract. Eng. Mater. Struct. 2017, 40, 706-731. [CrossRef]

81. Andrew-Munot, M.; Ibrahim, R. Remanufacturing process and its challenges. J. Mech. Eng. Sci. 2013, 4, 488-495. [CrossRef]

82. Huang, H.H.; Zhao, L.W.; Xiong, B.; Zhou, D.; Qian, Z.C.; Liu, Z.F. Magnetic Evaluation on Disassembly Damage of an Interference Fit Joint. J. Nondestruct. Eval. 2020, 39, 11. [CrossRef]

83. Mesa, J.A.; Illera, D.; Esparragoza, I.; Maury, H.; Gomez, H. Functional characterisation of mechanical joints to facilitate its selection during the design of open architecture products. Int. J. Prod. Res. 2018, 56, 7390-7404. [CrossRef]

84. Inderfurth, K.; Vogelgesang, S.; Langella, I.M. How yield process misspecification affects the solution of disassemble-to-order problems. Int. J. Prod. Econ. 2015, 169, 56-67. [CrossRef]

85. Hu, Y.; Srinivasan, R.; Spoll, J.; Ameta, G. Graph Based Method and Tool for Complete and Selective Disassembly Time Estimation in Early Design. J. Comput. Inf. Sci. Eng. 2015, 15, 10. [CrossRef]

86. Abdullah, N.; Azni Jafar, F.; Maslan, M.N. Experimental Design for Reverse Assembly Based Disassembly Process. Appl. Mech. Mater. 2014, 660, 1062-1066. [CrossRef]

87. Ridley, S.J.; Ijomah, W.L.; Corney, J.R. Improving the efficiency of remanufacture through enhanced pre-processing inspection-A comprehensive study of over 2000 engines at Caterpillar remanufacturing, UK. Prod. Plan. Control 2019, 30, 259-270. [CrossRef]

88. Suhariyanto, T.T.; Wahab, D.A.; Rahman, M.N.A. Multi-Life Cycle Assessment for sustainable products: A systematic review. J. Clean. Prod. 2017, 165, 677-696. [CrossRef]

89. Farahani, S.; Otieno, W.; Omwando, T. The optimal disposition policy for remanufacturing systems with variable quality returns. Comput. Ind. Eng. 2020, 140, 14. [CrossRef]

90. Paterson, D.A.P.; Ijomah, W.L.; Windmill, J.F.C. End-of-life decision tool with emphasis on remanufacturing. J. Clean. Prod. 2017, 148, 653-664. [CrossRef]

91. Jiang, Z.G.; Wang, H.; Zhang, H.; Mendis, G.; Sutherland, J.W. Value recovery options portfolio optimization for remanufacturing end of life product. J. Clean. Prod. 2019, 210, 419-431. [CrossRef]

92. Liu, T.; Kim, H.; Wang, F.B.; Zhu, D.R. Damage state assessment method for remanufacturing blanks based on magnetic and surface texture feature fusion. Int. J. Adv. Manuf. Technol. 2018, 95, 1777-1788. [CrossRef]

93. Lu, H.Y.; Li, Y.L.; Li, F.Y.; Zhang, X.Y.; Zhang, C.W.; Du, J.Y.; Li, Z.; Ran, X.J.; Li, J.F.; Wang, W.Q. Damage mechanism and evaluation model of compressor impeller remanufacturing blanks: A review. Front. Mech. Eng. 2019, 14, 402-411. [CrossRef]

94. Chen, W.J.; Chen, H.; Li, C.C.; Wang, X.L.; Cai, Q. Microstructure and fatigue crack growth of EA4T steel in laser cladding remanufacturing. Eng. Fail. Anal. 2017, 79, 120-129. [CrossRef]

95. Errington, M.; Childe, S.J. A business process model of inspection in remanufacturing. J. Remanuf. 2013, 3, 7. [CrossRef]

96. Lahrour, Y.; Brissaud, D. A Technical Assessment of Product/Component Re-manufacturability for Additive Remanufacturing. In 25th Cirp Life Cycle Engineering; Laurent, A., Leclerc, A., Niero, M., Dong, Y., Olsen, S.I., Owsianiak, M., Bey, N., Ryberg, M., Hauschild, M.Z., Eds.; Elsevier: Amsterdam, The Netherlands, 2018; Volume 69, pp. 142-147.

97. Jiang, X.Y.; Zhang, H.Y.; Song, B.X.; Yang, S.Q.; Wang, Z.S. Prediction for Remanufacturability of Used Parts Based on Extension Synthesize Evaluation; IEEE: New York, NY, USA, 2018; pp. 797-800.

98. Wang, H.D.; Ma, G.Z.; Xu, B.S.; Yong, Q.S.; He, P.F. Design and application of friction pair surface modification coating for remanufacturing. Friction 2017, 5, 351-360. [CrossRef]

99. Yang, S.S.; Nasr, N.; Ong, S.K.; Nee, A.Y.C. A holistic decision support tool for remanufacturing: End-of-life (EOL) strategy planning. Adv. Manuf. 2016, 4, 189-201. [CrossRef]

100. Favi, C.; Germani, M.; Luzi, A.; Mandolini, M.; Marconi, M. A design for EoL approach and metrics to favour closed-loop scenarios for products. Int. J. Sustain. Eng. 2017, 10, 136-146. [CrossRef]

101. Barkmeyer, M.; Kaluza, A.; Pastewski, N.; Thiede, S.; Herrmann, C. Assessment of end-of-life strategies for automation technology components. In 24th CIRP Conference on Life Cycle Engineering, Kamakura, Japan, 8-10 March 2017; Takata, S., Umeda, Y., Kondoh, S., Eds.; Elsevier: Amsterdam, The Netherlands, 2017; Volume 61, pp. 34-39.

102. Esquer, J.; Arvayo, J.A.; Alvarez-Chavez, C.R.; Munguia-Vega, N.E.; Velazquez, L. Cleaner production in a remanufacturing process of air compressors. Int. J. Occup. Saf. Ergon. 2017, 23, 83-91. [CrossRef]

103. Qin, P.P.; Jiang, D.X.; Wang, L.L.; Pan, X.Q.; Che, C.C. Study on the influence of paint-removal process on the performance of the used parts for remanufacturing. In Proceedings of the 5th International Conference on Advanced Design and Manufacturing Engineering, Shenzhen, China, 19-20 September 2015; Jiang, Z., Ed.; Atlantis Press: Paris, France, 2015; Volume 39, pp. 846-851. 
104. Li, M.Z.; Liu, W.W.; Short, T.; Qing, X.C.; Dong, Y.Z.; He, Y.M.; Zhang, H.C. Pre-treatment of remanufacturing cleaning by use of supercritical $\mathrm{CO}_{2}$ in comparison with thermal cleaning. Clean Technol. Environ. Policy 2015, 17, 1563-1572. [CrossRef]

105. Feng, C.; Liang, J.; Gong, C.Y.; Pai, W.Y.; Liu, S.F. Repair volume extraction method for damaged parts in remanufacturing repair. Int. J. Adv. Manuf. Technol. 2018, 98, 1523-1536. [CrossRef]

106. Liu, M.Z.; Liu, C.H.; Ge, M.G.; Zhang, Y.; Liu, Z.Q. The online quality control method for reassembly based on state space model J. Clean. Prod. 2016, 137, 644-651. [CrossRef]

107. Liu, W.W.; Tang, Z.J.; Liu, X.Y.; Wang, H.J.; Zhang, H.C. A Review on in-situ monitoring and adaptive control technology for laser cladding remanufacturing. In Proceedings of the 24th CIRP Conference on Life Cycle Engineering, Kamakura, Japan, 8-10 March 2017; Takata, S., Umeda, Y., Kondoh, S., Eds.; Elsevier: Amsterdam, The Netherlands, 2017; Volume 61, pp. $235-240$.

108. Liu, X.; Xia, X.H.; Wang, L. New method for detecting surface defects of the rotational parts in remanufacturing service. In Proceedings of the 2017 5th International Conference on Machinery, Materials and Computing Technology, Beijing, China, 25-26 March 2017; Hou, H., Han, Z., Eds.; Atlantis Press: Paris, France, 2017; Volume 126, pp. 714-724.

109. Kawasaki, K.; Tsuji, I.; Gunbara, H.; Houjoh, H. Method for remanufacturing large-sized skew bevel gears using CNC machining center. Mech. Mach. Theory 2015, 92, 213-229. [CrossRef]

110. Shen, W.L.; Pang, K.; Liu, C.H.; Ge, M.G.; Zhang, Y.R.; Wang, X.Q. The quality control method for remanufacturing assembly based on the Jacobian-torsor model. Int. J. Adv. Manuf. Technol. 2015, 81, 253-261. [CrossRef]

111. Yu, J.-M.; Lee, D.-H. Scheduling algorithms for job-shop-type remanufacturing systems with component matching requirement. Comput. Ind. Eng. 2018, 120, 266-278. [CrossRef]

112. Ge, M.; Hu, J.; Liu, M.; Zhang, Y.J. Reassembly classification selection method based on the Markov Chain. Assem. Autom. 2018, 38. [CrossRef]

113. Williams, S.V.; Appiah-Kubi, P.; Atuahene, I.; Park, N. Systems analysis and remanufacturing: Testing of automotive electronics. In Proceedings of the Industrial and Systems Engineering Research Conference, Montreal, Canada, 24-25 May 2021; pp. 1-7.

114. Changliang, S.; Hao, Z.; Shiyun, D.; Weixue, T. Novel nondestructive testing applications in old automotive engine. IOP Conf. Ser. 2017, 182, 012060. [CrossRef]

115. Tant, K.M.M.; Mulholland, A.J.; Curtis, A.; Ijomah, W.L. Design-for-testing for improved remanufacturability. J. Remanuf. 2019, 9, 61-72. [CrossRef]

116. Gao, Y.C.; Feng, Y.X.; Wang, Q.R.; Zheng, H.; Tan, J.R. A multi-objective decision making approach for dealing with uncertainty in EOL product recovery. J. Clean. Prod. 2018, 204, 712-725. [CrossRef]

117. Shi, J.; Zhang, W.; Zhang, S.; Wang, W.; Lin, J.; Feng, R. A new environment-aware scheduling method for remanufacturing system with non-dedicated reprocessing lines using improved flower pollination algorithm. J. Manuf. Syst. 2020, 57, 94-108. [CrossRef]

118. Dung, V.T.; Tjahjowidodo, T. Automatic weld bead detection on free-form surface parts for remanufacturing processes. In Proceedings of the 2017 IEEE International Conference on Advanced Intelligent Mechatronics, Munich, Germany, 3-7 July 2017; pp. 1065-1070.

119. Zhang, C.X.; Liu, C.H.; Chen, J.Q.; Li, Q.; He, K.; Gao, M.D.; Cai, W. The coupling mechanism of reassembly quality with uncertainty of remanufactured parts. Assem. Autom. 2019, 39, 548-555. [CrossRef]

120. Shi, J.L.; Wang, Y.J.; Cheng, J.S. Remanufacturability evaluation for waste mechanical product from technical point of view. In Proceedings of the 2017 Global Conference on Mechanics and Civil Engineering, Guangzhou, China, 24-25 June 2017; Zhou, P., Wang, Z., Liang, B., Eds.; Atlantis Press: Paris, France, 2017; Volume 132, pp. 401-404.

121. Daraba, D.; Alexandrescu, I.M.; Daraba, C. Research on the injectors remanufacturing. In Innovative Ideas in Science 2016; Lemle, L.D., Ed.; Iop Publishing Ltd: Bristol, UK, 2017; Volume 200.

122. Serb, G.D.P.; Serb, I.P. Applying scenario based learning to study the impact of remanufacturing on the stepper motor control. In Proceedings of the 2019 11th International Symposium on Advanced Topics in Electrical Engineering, Bucharest, Romania, 28-30 March 2019.

123. Du, Y.B.; Zheng, Y.S.; Wu, G.; Tang, Y. Decision-making method of heavy-duty machine tool remanufacturing based on AHPentropy weight and extension theory. J. Clean. Prod. 2020, 252, 12. [CrossRef]

124. Peng, S.T.; Li, T.; Wang, X.L.; Dong, M.M.; Liu, Z.C.; Shi, J.L.; Zhang, H.C. Toward a Sustainable Impeller Production: Environmental Impact Comparison of Different Impeller Manufacturing Methods. J. Ind. Ecol. 2017, 21, S216-S229. [CrossRef]

125. Nassehi, A.; Colledani, M. A multi-method simulation approach for evaluating the effect of the interaction of customer behaviour and enterprise strategy on economic viability of remanufacturing. CIRP Ann.-Manuf. Technol. 2018, 67, 33-36. [CrossRef]

126. Liu, C.H.; Zhu, Q.H.; Wei, F.F.; Rao, W.Z.; Liu, J.J.; Hu, J.; Cai, W. An integrated optimization control method for remanufacturing assembly system. J. Clean. Prod. 2020, 248, 10. [CrossRef]

127. Afshar-Bakeshloo, M.; Jolai, F.; Bozorgi-Amiri, A. A bi-objective manufacturing/remanufacturing system considering downward substitutions between three markets. J. Manuf. Syst. 2021, 58, 75-92. [CrossRef]

128. Paterson, D.A.P.; Ijomah, W.; Windmill, J.F.C. An analysis of end-of-life terminology in the carbon fiber reinforced plastic industry. Int. J. Sustain. Eng. 2016, 9, 130-140. [CrossRef]

129. Inderfurth, K. Impact of uncertainties on recovery behavior in a remanufacturing environment: A numerical analysis. Int. J. Phys. Distrib. Logist. Manag. 2005, 35, 318-336. [CrossRef] 
130. Denizel, M.; Ferguson, M.; Souza, G.C. Multiperiod Remanufacturing Planning With Uncertain Quality of Inputs. IEEE Trans. Eng. Manag. 2010, 57, 394-404. [CrossRef]

131. Wen, H.J.; Liu, M.Z.; Liu, C.Y.; Liu, C.H. Remanufacturing production planning with compensation function approximation method. Appl. Math. Comput. 2015, 256, 742-753. [CrossRef]

132. Khan, M.A.; Mittal, S.; West, S.; Wuest, T. Review on upgradability-A product lifetime extension strategy in the context of product service systems. J. Clean. Prod. 2018, 204, 1154-1168. [CrossRef]

133. Ngu, H.J.; Lee, M.D.; Bin Osman, M.S. Review on current challenges and future opportunities in Malaysia sustainable manufacturing: Remanufacturing industries. J. Clean Prod. 2020, 273, 123071. [CrossRef]

134. Zhang, X.; Zhang, M.; Zhang, H.; Jiang, Z.; Liu, C.; Cai, W. A review on energy, environment and economic assessment in remanufacturing based on life cycle assessment method. J. Clean. Prod. 2020, 255, 120160. [CrossRef]

135. Ardente, F.; Talens Peiró, L.; Mathieux, F.; Polverini, D. Accounting for the environmental benefits of remanufactured products: Method and application. J. Clean. Prod. 2018, 198, 1545-1558. [CrossRef]

136. Sutherland, J.W.; Adler, D.P.; Haapala, K.R.; Kumar, V. A comparison of manufacturing and remanufacturing energy intensities with application to diesel engine production. CIRP Ann. 2008, 57, 5-8. [CrossRef]

137. Chen, Y.; Wang, J.F.; Yu, Y.L. A Study on Consumers' Willingness to Pay for Remanufactured Products: A Study Based on Hierarchical Regression Method. Front. Psychol. 2019, 10, 9. [CrossRef]

138. Circularity Gap Report. 2019 Circularity Gap Report Reveals that the World is only 9\% Circular and the Trend is Negative; European Circular Economy Stakeholder Platform: Baden, Switzerland, 2019; Available online: https:/ / circulareconomy.europa.eu/platform/ en/news-and-events / all-news/2019-circularity-gap-report-reveals-world-only-9-circular-and-trend-negative (accessed on 1 March 2021).

139. Abbey, J.D.; Meloy, M.G.; Guide, V.D.R., Jr.; Atalay, S. Remanufactured products in closed-loop supply chains for consumer goods. Prod. Oper. Manag. 2015, 24, 488-503. [CrossRef]

140. Atasu, A.; Guide, V.D.R., Jr.; van Wassenhove, L.N. So what if remanufacturing cannibalizes my new product sales? Calif. Manag. Rev. 2010, 52, 56-76. [CrossRef]

141. Liu, H.; Liang, L.; Zhang, H.; Li, W. Study on consumers' awareness and purchase behavior of remanufactured products in China. Oper. Res. Manag. Sci. 2009, 18, 159-163.

142. Xiong, Y.; Zhao, Q.; Zhou, Y. Manufacturer-remanufacturing vs supplier-remanufacturing in a closed-loop supply chain. Int. J. Prod. Econ. 2016, 176, 21-28. [CrossRef]

143. Wei, S.; Cheng, D.; Sundin, E.; Tang, O. Motives and barriers of the remanufacturing industry in China. J. Clean. Prod. 2015, 94, 340-351. [CrossRef]

144. Tian, G.; Zhang, H.; Feng, Y.; Jia, H.; Zhang, C.; Jiang, Z.; Li, Z.; Li, P. Operation patterns analysis of automotive components remanufacturing industry development in China. J. Clean. Prod. 2017, 164, 1363-1375. [CrossRef]

145. Xia, X.; Li, J.; Tian, H.; Zhou, Z.; Li, H.; Tian, G.; Chu, J. The construction and cost-benefit analysis of end-of-life vehicle disassembly plant: A typical case in China. Clean Technol. Environ. Policy 2016, 18, 2663-2675. [CrossRef]

146. Rahimifard, S.; Coates, G.; Staikos, T.; Edwards, C.; Abu-Bakar, M. Barriers, drivers and challenges for sustainable product recovery and recycling. Int. J. Sustain. Eng. 2009, 2, 80-90. [CrossRef]

147. Kurilova-Palisaitiene, J.; Sundin, E.; Poksinska, B. Remanufacturing challenges and possible lean improvements. J. Clean. Prod. 2018, 172, 3225-3236. [CrossRef]

148. Parker, D.; Riley, K.; Robinson, S.; Symington, H.; Tewson, J.; Jansson, K.; Ramkumar, S.; Peck, D. Remanufacturing Market Study; European Remanufacturing Network (ERN): London, UK, 2015; p. 145. Available online: https://www.remanufacturing.eu/ assets / pdfs/remanufacturing-market-study.pdf (accessed on 1 March 2021).

149. Amelia, L.; Wahab, D.A.; Che Haron, C.H.; Muhamad, N.; Azhari, C.H. Initiating automotive component reuse in Malaysia. J. Clean. Prod. 2009, 17, 1572-1579. [CrossRef]

150. Rathore, P.; Kota, S.; Chakrabarti, A. Sustainability through remanufacturing in India: A case study on mobile handsets. J. Clean. Prod. 2011, 19, 1709-1722. [CrossRef]

151. Zhang, T.; Chu, J.; Wang, X.; Liu, X.; Cui, P. Development pattern and enhancing system of automotive components remanufacturing industry in China. Resour. Conserv. Recycl. 2011, 55, 613-622. [CrossRef]

152. Vasudevan, H.; Kalamkar, V.; Terkar, R. Remanufacturing for Sustainable Development: Key Challenges, Elements, and Benefits. Int. J. Innov. Manag. Technol. 2012, 3, 84-89. [CrossRef]

153. Hammond, R.; Amezquita, T.; Bras, B.A. Issues in the Automotive Parts Remanufacturing Industry: Discussion of Results from Surveys Performed among Remanufacturers. Int. J. Eng. Des. Autom. 1998, 4, 27-46.

154. Steinhilper, R. Recent trends and benefits of remanufacturing: From closed loop businesses to synergetic networks. In Proceedings of the 2nd International Symposium on Environmentally Conscious Design and Inverse Manufacturing, Tokyo, Japan, 11-15 December 2001; pp. 481-488.

155. Golinska, P.; Kawa, A. Remanufacturing in automotive industry: Challenges and limitations. J. Ind. Eng. Manag. $2011,4,453-466$. [CrossRef]

156. Matsumoto, M.; Umeda, Y. An analysis of remanufacturing practices in Japan. J. Remanuf. 2011, 1, 2. [CrossRef]

157. Ikeda, A. Remanufacturing of Automotive Parts in Japanese Market. Procedia CIRP 2017, 61, 800-803. [CrossRef] 
158. Gamage, J.R.; Ijomah, W.L.; Windmill, J. Design for cleaning (DfC) in automotive remanufacturing. In Proceedings of the International Conference on Remanufacturing-ICOR 2015, Amsterdam, The Netherlands, 14-16 June 2015; pp. 148-154.

159. Martínez, M.; Herrera, M.; López-Gijón, J.; Herrera-Viedma, E. H-Classics: Characterizing the concept of citation classics through H-index. Scientometrics 2014, 98, 1971-1983. [CrossRef]

160. Hirsch, J.E. An index to quantify an individual's scientific research output. Proc. Natl. Acad. Sci. USA 2005, 102, 16569-16572. [CrossRef]

161. Savaskan, R.C.; Bhattacharya, S.; van Wassenhove, L.N. Closed-loop supply chain models with product remanufacturing. Manag. Sci. 2004, 50, 239-252. [CrossRef]

162. Gungor, A.; Gupta, S.M. Issues in environmentally conscious manufacturing and product recovery: A survey. Comput. Ind. Eng. 1999, 36, 811-853. [CrossRef]

163. Guide, V.D.R. Production planning and control for remanufacturing: Industry practice and research needs. J. Oper. Manag. 2000, 18, 467-483. [CrossRef]

164. Lieder, M.; Rashid, A. Towards circular economy implementation: A comprehensive review in context of manufacturing industry. J. Clean. Prod. 2016, 115, 36-51. [CrossRef]

165. Ilgin, M.A.; Gupta, S.M. Environmentally conscious manufacturing and product recovery (ECMPRO): A review of the state of the art. J. Environ. Manag. 2010, 91, 563-591. [CrossRef] [PubMed]

166. Savaskan, R.C.; van Wassenhove, L.N. Reverse channel design: The case of competing retailers. Manag. Sci. 2006, 52, 1-14. [CrossRef]

167. Atasu, A.; Sarvary, M.; van Wassenhove, L.N. Remanufacturing as a Marketing Strategy. Manag. Sci. 2008, 54, 1731-1746. [CrossRef]

168. Ferrer, G.; Swaminathan, J.M. Managing new and remanufactured products. Manag. Sci. 2006, 52, 15-26. [CrossRef]

169. Ferguson, M.E.; Toktay, L.B. The effect of competition on recovery strategies. Prod. Oper. Manag. 2006, 15, 351-368. [CrossRef]

170. Debo, L.G.; Toktay, L.B.; van Wassenhove, L.N. Market segmentation and product technology selection for remanufacturable products. Manag. Sci. 2005, 51, 1193-1205. [CrossRef]

171. Kerin, M.; Pham, D.T. Smart remanufacturing: A review and research framework. J. Manuf. Technol. Manag. 2020, 31, 1205-1235. [CrossRef]

172. Kerin, M.; Pham, D.T. A review of emerging industry 4.0 technologies in remanufacturing. J. Clean. Prod. 2019, $237,117805$. [CrossRef]

173. Liu, M.Z.; Liu, C.H.; Ge, M.G.; Zhang, Y.; Zhu, Q.H. Remanufacturing in Industry 4.0. Front. Eng. Manag. 2016, 3, 144-146. [CrossRef]

174. Yang, S.; MR, A.R.; Kaminski, J.; Pepin, H. Opportunities for Industry 4.0 to Support Remanufacturing. Appl. Sci. 2018, 8, 1177. [CrossRef]

175. Rajput, S.; Singh, S.P. Industry 4.0 model for integrated circular economy-reverse logistics network. Int. J. Logist. Res. Appl. 2021, 107, 1-41. [CrossRef]

176. Schmidt, B.; Wang, L.; Galar, D. Semantic Framework for Predictive Maintenance in a Cloud Environment. Procedia CIRP 2017, 62, 583-588. [CrossRef]

177. Osti, F.; Ceruti, A.; Liverani, A.; Caligiana, G. Semi-automatic Design for Disassembly Strategy Planning: An Augmented Reality Approach. Procedia Manuf. 2017, 11, 1481-1488. [CrossRef]

178. Hooshyar Telegraphi, A.; Bulgak, A.A. A mathematical model for designing a reliable cellular hybrid manufacturingremanufacturing system considering alternative and contingency process routings. SN Appl. Sci. 2021, 3, 356. [CrossRef] [PubMed]

179. Bazan, E.; Jaber, M.Y.; Zanoni, S. A review of mathematical inventory models for reverse logistics and the future of its modeling: An environmental perspective. Appl. Math. Modelling 2016, 40, 4151-4178. [CrossRef]

180. Rezaei, J. A Systematic Review of Multi-criteria Decision-making Applications in Reverse Logistics. Transp. Res. Procedia 2015, 10, 766-776. [CrossRef]

181. Zhang, X.; Li, Z.; Wang, Y.; Yan, W. An Integrated Multicriteria Decision-Making Approach for Collection Modes Selection in Remanufacturing Reverse Logistics. Processes 2021, 9, 631. [CrossRef]

182. Karvonen, I.; Jansson, K.; Behm, K.; Vatanen, S.; Parker, D. Identifying recommendations to promote remanufacturing in Europe. J. Remanuf. 2017, 7, 159-179. [CrossRef]

183. Hatcher, G.D.; Ijomah, W.L.; Windmill, J.F.C. Design for remanufacture: A literature review and future research needs. J. Clean. Prod. 2011, 19, 2004-2014. [CrossRef] 